\title{
Synchrotron FTIR Hydrocarbon Fluid Inclusion Microanalysis Applied to Diagenetic History and Fluid Flow Reconstruction in Reservoir Appraisal
}

\author{
N. Guilhaumou' and P. Dumas ${ }^{2}$ \\ 1 Muséum National d'Histoire Naturelle, Case 52.USM 205 LEME - UMS CNRS 2679 NanoAnalyses \\ 57 , rue Cuvier 75005, Paris - France \\ 2 Soleil Synchrotron, L'Orme des Merisiers, BP 48, Saint-Aubin, 91192 Gif-sur-Yvette Cedex - France \\ e-mail: guilhau@mnhn.fr - paul.dumas@synchrotron-soleil.fr
}

\begin{abstract}
Résumé - Microanalyse par FTIR avec une source synchrotron des inclusions d'hydrocarbures. Application à la reconstitution des conditions de la diagenèse et des circulations fluides dans les réservoirs - Au cours de la diagenèse des réservoirs, des gouttelettes d'hydrocarbures présentes dans les fluides minéralisateurs sont piégées dans des lacunes de cristallisation sous forme d'inclusions fluides (FI). En combinant la composition de ces hydrocarbures à leur densité et leurs paramètres volumiques, mesurés par microthermométrie, on peut modéliser leurs isochores spécifiques dans un champ de pression-température (P-T). Le piégeage de familles d'inclusions synchrones et de compositions différentes permet de déterminer les conditions P-T de migration des fluides organiques ainsi que les conditions de la diagenèse au cours d'une évolution géologique. À partir de la composition de ces inclusions, on peut étudier les mécanismes importants pour les qualités des réservoirs, tels que le craquage et la biodégradation de la matière organique, les injections de gaz comme le $\mathrm{CO}_{2}$ et le $\mathrm{CH}_{4}$.

La microspectrométrie infrarouge a fait des progrès spectaculaires ces dernières années grâce à l'utilisation des sources synchrotron, particulièrement stables et à forte brillance dans le moyen et le proche infrarouge. La composition d'inclusions d'hydrocarbures de très petite dimension (quelques microns) piégées dans des minéraux tels que le quartz, la fluorine et les carbonates peut être obtenue individuellement et de manière non destructive par microscopie infrarouge à transformée de Fourier (SFTIR). Cette technique utilise une source synchrotron comme radiation excitatrice. Nous présentons les potentialités de cette méthode de microanalyse avec des exemples de résultats significatifs dans le domaine des réservoirs pétroliers, en contexte de bassins sédimentaires et de zones sous chevauchements.
\end{abstract}

Dans les surcroissances de quartz des réservoirs gréseux, la dimension des inclusions d'hydrocarbures est de l'ordre de $10 \mu \mathrm{m}$ ou inférieure. Nous avons pu analyser plusieurs générations d'inclusions. Ces analyses ont été effectuées dans les grès de la mer du Nord (Brent, région de Dunbar), les bassins d'avantpays des régions subandines (Venezuela, Colombie) et les formations carbonatées du nord de la Tunisie et du Pakistan oriental. Dans la plupart des cas, nous avons pu réaliser et étudier des images moléculaires et procéder à l'analyse semi-quantitative in situ des composés organiques inclus (rapports $\mathrm{CH}_{3} / \mathrm{CH}_{2}$ ) et des molécules associées telles que $\mathrm{CO}_{2}, \mathrm{H}_{2} \mathrm{O}, \mathrm{CH}_{4}$. La fiabilité des résultats des rapports $\mathrm{CH}_{3} / \mathrm{CH}_{2}$ a été vérifiée en effectuant une comparaison avec les compositions obtenues par chromatographie en phase gazeuse après extraction individuelle du contenu organique des inclusions de grande dimension $(500 \mu \mathrm{m})$ dans la fluorine. Les phases solides présentes comme minéraux fils (issus de la solution initiale) dans les 
phases hydrocarbonées ont pu également être identifiées. Elles mettent en évidence l'importance des mécanismes de transformation sulfates-carbonates (TSR) en présence de composés organiques dans les sédiments riches en évaporites.

À partir des compositions obtenues par SFTIR, nous avons pu, dans ces exemples, calculer les conditions $\mathrm{P}-\mathrm{T}$ de la diagenèse. L'histoire de la migration des fluides dans des environnements de réservoirs gréseux, dans des zones de foothills comme les régions subandines du Venezuela et de la Colombie, ainsi que l'historique de la circulation des fluides en relation avec les évolutions tectoniques, ont pu être reconstitués. Ce travail a été réalisé à l'aide du logiciel Trustpack (IFP), par l'équipe du Département Géologie de l'IFP dans les gîtes minéraux associés aux déformations le long de l'accident de Zagouhan (Tunisie septentrionale) et du nord de la chaîne de Kir Thar (Pakistan) ainsi que dans les réservoirs carbonatés de la région de Chorgali (bassin du Nord Potwar, Pakistan).

\begin{abstract}
Synchrotron FTIR Hydrocarbon Fluid Inclusion Microanalysis Applied to Diagenetic History and Fluid Flow Reconstruction in Reservoir Appraisal - In sandstones, siliceous diagenetic overgrowths may commonly contain several generations of hydrocarbon fluid inclusions (FI's), generally of size no more than $10 \mu$. We successfully analyzed such inclusions in North sea sandstones from the Dunbar area, subthrusted reservoirs such as sub-Andean basins (Venezuelian and Colombian foothills) and carbonaceous series in areas of Pakistan, using synchrotron infrared microscopy. We addressed, for each case studied, molecular identification and mapping of the components, i.e. hydrocarbon content, and additional molecules such as $\mathrm{CO}_{2}, \mathrm{H}_{2} \mathrm{O}$, in small volumes in their liquid and gas phase as well as the solid phases often associated as products or mechanically entrapped minerals. Semi-quantitative analysis leads to determination of the average composition of each inclusion, i.e equivalent aliphatic chain length ( $\mathrm{CH}_{2} / \mathrm{CH}_{3}$ ratios), $\mathrm{CO}_{2}$ and $\mathrm{CH}_{4}$ content. The quantitative method for hydrocarbon chain length measurements was tested first on some exceptionally large FI's (up to $500 \mu \mathrm{m}$ ) previously analyzed by gas chromatography after individual extraction. Homogeneity and /or heterogeneity of trapping as well association of oil with water or their separation is shown for each generation of FI corresponding to a specific organic fluid migration in sandstones from the Brent formation of Dunbar (North sea), and in siliceous reservoirs of subandin basins (Venezuelian and Colombian foothills). Microanalyses of solid phases closely associated within oil in such FI's indicate conditions of the dissolution-recrystallisation processes. Results are particularly promising in carbonaceous reservoirs of Northern Pakistan (Chorgali area, North Potwar basin) where first results pinpoint the effect of TSR mechanism in environments where evaporites were first deposited.

$P V T$ modeling of isochores using semi-quantitative SFTIR analyses leads to reconstruction of P-T conditions of diagenesis. Therefore by combining these results with data from organic matter (Genex modeling) and petrography, the onset of cementation was established in the Venezuelian and Colombian Foothills. The path of fluid migration along geological history was then reconstructed with Thrustpack $2 D$ thermal modeling (IFP software), in Tunisian and Pakistani ore deposits and in the carbonaceous reservoir of Chorgali.
\end{abstract}

\section{INTRODUCTION}

Hydrocarbon bearing fluid inclusions (FI's) can be systematically entrapped as small droplets of oil/gas in diagenetic minerals along migration paths of organic matter in numerous reservoirs. A combination of information on trapping temperature and molecular composition with isochoric Pressure Volume Temperature (PVT) modeling of these FI's leads to straightforward definition of the conditions of organic matter migration and diagenetic processes in petroleum occurrences. A knowledge of their individual composition is of key importance, because FI's act as a sealed container of non-contaminated fluid. The molecular composition of each oil FI can be assessed by in situ FTIR microanalysis, which is a non destructive technique, and then may be correlated directly to its density measured by microthermometry. These combined data allow PVT modeling and calculation of the isochoric path of a single generation of fluid inclusion. Entrapment of coeval hydrocarbon and water in FI's allows one to specify the Pressure-Temperature (PT) conditions of diagenesis reconstructed during evolution of reservoir rocks. In situ cracking of oil, biodegradation and $\mathrm{CO}_{2}$ input into reservoirs can also be assessed.

During recent years, significant technological advances have been made in Infrared microspectrometry, in particular the source brightness has been improved by two orders of magnitude using a synchrotron source (see related article of F. Baudelet et al., 2005 in this issue). This has allowed in situ 
quantitative non destructive molecular analyses by synchrotron Fourier transform infrared (SFTIR) spectroscopy of particles a few microns in size. The successive generations of hydrocarbon fluid inclusions entrapped in diagenetic minerals (quartz, fluorite, carbonates) formed in reservoirs are identified and analysed. The potentiality of synchrotron infrared microspectrometry was investigated to determine an understanding of diagenesis and aids in Pressure Temperature modeling of petroleum reservoirs and carrier beds in various geological areas. Here we report and discuss some of the most significant results.

As oil is allowed to migrate in reservoirs as a multiphase mixture of liquid hydrocarbons, gas and water (Rudkiewicz et al., 1994), this fluid is entrapped in diagenetic minerals as hydrocarbon-bearing fluid inclusions if cementation is active. The knowledge of individual FI composition is of key importance, because FI's acts as a sealed container of non-contaminated fluid. Since their first description by Murray (1957) in fluorite, there have been many studies involving the composition and densities of these fluid inclusions (FI's) for the understanding of Pressure-Temperature conditions of fluid circulations in sedimentary basins and ore deposits (review in Roedder, 1984; Mc. Limans, 1987; Karlsen et al., 1993; Goldstein \& Reynolds, 1994; Goldstein, 2001). A combination of trapping temperature and chemical composition of the oil with isochoric PVT modeling of oil bearing fluid inclusions lead directly to information on the PressureTemperature (PT) conditions of the fluid circulations and the associated mechanism of diagenesis occurring in the sediments during compaction and syntectonic deformation in subthrusted petroleum reservoirs (Mc Limans, 1987; Larroque et al., 1996, Guilhaumou et al., 2000).

Whilst the trapping temperature of FI's is usually measured by microthermometry (Roedder, 1984), the chemical composition of entrapped oil has been obtained tentatively by various destructive techniques involving decrepitation, (Barker \& Underwod, 1992; Macleod et al., 1994, 1995, 1996) or crushing and leachate analysis (George et al., 1998). In exceptionally large fluid inclusions (Guilhaumou et al., 2000), the composition and biomarkers data were obtained by individual extraction under the microscope and GCMS analysis, but the analysis of the C1-C5 fraction was not possible. Jones and Macleod (1996) proposed a sophisticated methodology to extract and clean the sample before crushing and leachate analysis. However, this method is time consuming. The main limitations remain a possible contamination during the extraction and the mixing of the several generations of oil usually observed by microscopy in the same minerals. Additionally oil-water fluid inclusions are frequently encountered in heterogeneous trapping that precludes linking the individual homogenization temperature with the real composition for PVT modeling. This points towards the necessary use of individual composition of FI's representatives of one of the several oil migrations. This could only be obtained by analysis and mapping at a microscopic scale. In the last decades, advances in molecular infrared microspectrometry (Guilhaumou et al., 1988; 1990 a b, 1998; Rankin et al., 1990; Pironon et Bares, 1990, Pironon et al., 2001) allow quantitative non destructive molecular analyses to be performed in a single fluid inclusion under a microscope. The size of the FI analyzed is currently restricted to the wavelength of incident beam $(20 \mu \mathrm{m})$ when using a conventional source such as a Globar (Barres et al.,1987). The interfacing of a Synchrotron source to a microscope aims at overcoming this limit and performing analyses and mapping of the components at the scale of a few microns (Guilhaumou et al., $1998 \mathrm{~b}, 2000,2004)$. The origin of the poor lateral resolution of conventional FT-IR microscopy is intrinsic, depending upon the reduced photon flux reaching the detector when a conventional black body source is used and when apertures are set to less than $40-50 \mu \mathrm{m}$ diameters. The advantage of a Synchrotron source consists in high brightness and high stability of the beam allowing the intrinsic wavelength limit to be overcome (Reffner et al., 1995; Polack, 1999).

Semi-quantitative analysis can be performed based on the change of the integrated intensities of each vibrator inside the fluid inclusions. Using internal calibration, we may then link directly individual composition to density. Over the same period, progress in isochoric modeling using modified Equations of State (Ungerer and Batut, 1997; Mougin, 1999; Aplin et al., 1999; Guilhaumou et al., 2000; Thiery et al., 2000) leads to the possibility to calculate thermodynamic properties, i.e the phase envelopes and isochoric P-T path from analytical data of petroleum FI's.

\section{EXPERIMENTAL}

First experiments to test the potentiality of the method were carried out at the U2B line in Brookhaven (Guilhaumou et al., 1998), Most of the data presented below were acquired subsequently at LURE (Orsay, France) on the Mirage beam line (Superaco) in the mid infrared range.

\subsection{Analytical Conditions}

The MIRAGE beamline, at LURE used a synchrotron infrared source at SuperACO (Orsay, France; Reffner et al., 1995; Polack, et al. 1999). The IR microspectroscopy beamline was equipped with a Nic-Plan IR microscope coupled to a Magna 560 FTIR spectrometer. The microscope operates in confocal mode, where the focusing Schwarzschild objective has a magnification of $\mathrm{x} 32(\mathrm{NA}=0.85)$ and the collection Schwarzschild objective a magnification of x10 $(\mathrm{NA}=0.71)$. The area of illumination was determined with an adjustable aperture placed at an intermediate focal point, and re-imaged 
onto the sample. The upper and lower apertures are manually adjustable down to approximately $2 \times 2 \mu \mathrm{m}^{2}$. This aperture sets the probed area close to that obtained by Raman microscopy $\left(1 \times 1 \mu \mathrm{m}^{2}\right)$. The beam interface provides a beam that passes about $70 \%$ of its energy through a $12.5-\mu \mathrm{m}$ pinhole. Due to its reduced source size and high collimation properties, a synchrotron IR source is more efficiently coupled to the low acceptance of the confocal microscope, while its higher spectral luminescence (brightness) allows us to keep signal-to-noise ratios at diffraction-limited resolutions. In the present study, spectra were collected in transmission mode, at either $8 \mathrm{~cm}^{-1}$ or $4 \mathrm{~cm}^{-1}$ resolution using the Atlus software (Thermo Nicolet Instruments). Data collection was performed using a dual remote masking aperture to define the sample area and minimize diffraction. The final format of the data was in absorbance units, calculated using the background collected through atmosphere. For each spectrum, a minimum of 512 scans were accumulated. A Happ-Genzel apodization function was applied for Fourier processing. Peak positions were determined using the Nicolet Omnic software (based on a polynomial least squares method) that allowed positions to be determined to within $1 \mathrm{~cm}^{-1}$. The microscope was equipped with a computer-controlled $\mathrm{x} / \mathrm{y}$ stage allowing acquisition of profiles or maps in the sample. To prevent absorption from the atmosphere (water and $\mathrm{CO}_{2}$ ), the system was purged by dry nitrogen. Maps were scanned in steps of $3 \mu \mathrm{m}$ in both directions. The synchrotron beam was apertured to produce a $3-\mu \mathrm{m}$ square spot .

\subsection{Semi quantitative analysis}

\subsubsection{Molecular Mapping of the Components Inside Fluid Inclusions}

In IR spectroscopy, there is a linear relationship between the integrated intensity of an absorption band (in units of absorption) and the product of concentration times thickness for a given vibrator. The spectra recorded by FTIR reflect the integrated intensity of each component in the fluid inclusions and obey the Beer Lambert law (Herzberg, 1951; Colthup, 1990). Molecular mapping of each of the components inside a single fluid inclusion can be performed using the integrated intensities of each vibrator. The spectral cut off values were at 2000 $\mathrm{cm}^{-1}$ in quartz and calcite and at $800 \mathrm{~cm}^{-1}$ in fluorite. We have performed such analysis on two distinct oil FI's coming from MVT fluorite deposits in Pakistan and Tunisia and having similar characteristics, as shown by optical observations in transmitted light (Fig. 1). At room temperature the fluid is separated into a liquid and a vapor phase in thermodynamic equilibrium. Some brownish solid phases appear that may be bitumens or asphaltens. In the inclusion from Pakistan, a great deal of data could be extracted from the spectra, in the range $2600-1000 \mathrm{~cm}^{-1}$ (fluorite matrix cut off at $800 \mathrm{~cm}^{-1}$ ). A typical infrared spectrum (Fig. $2 a$ and $2 b$ ) shows the pres- ence of $\mathrm{CO}_{2}$ under pressure (single peak at $2338 \mathrm{~cm}^{-1}$ ) linear alkanes (peaks at $1475-1370 \mathrm{~cm}^{-1}, 2860-3000 \mathrm{~cm}^{-1}$ ) aromatics (peak at $1610 \mathrm{~cm}^{-1}$ ). A weak peak at $1300 \mathrm{~cm}^{-1}$ could correspond to the C-O-C absorption of esters and ketones. Alkyl $\mathrm{NO}_{2}$ may be also indicated by the shoulder at $1494 \mathrm{~cm}^{-1}$. Water is not detected (no peak at $1640 \mathrm{~cm}^{-1}$ and in the range 3600-3200 $\mathrm{cm}^{-1}$ ) and $\mathrm{CH}_{4}$ content is very low (weak peak at $1304 \mathrm{~cm}^{-1}$ ). We then scanned the inclusion in a raster fashion (step size $3 \mu \mathrm{m}$ ) in order to obtain the chemical map of the inclusion (Fig. $2 \mathrm{C}$ to $2 \mathrm{~F}$ ). It is clearly seen that the $\mathrm{CO}_{2}$ and some aromatic $\mathrm{C}-\mathrm{H}$ stretch modes are located mainly in the vapor phase, and the aliphatics, alkyls and other aromatics in the liquid phase.

The inclusion from Tunisia shows a different composition (Fig. 3). The spectra A to C, taken respectively in the external part, vapor part and liquid part of the FI, show the presence of $\mathrm{CO}_{2}$ under pressure (single peak at $2336 \mathrm{~cm}^{-1}$ ), $\mathrm{CH}_{4}$ (peaks at 1310 and $3010 \mathrm{~cm}^{-1}$ ) aliphatic hydrocarbons (peaks at 2870, $2960, \mathrm{~cm}^{-1}$, and $2925-2850 \mathrm{~cm}^{-1}$ ) and water (peaks at 1640 and $3600-3200 \mathrm{~cm}^{-1}$ ) as main components. Note that aromatic $\mathrm{C}-\mathrm{H}$ stretching are not detected. Molecular mapping shows that $\mathrm{CH}_{4}$ is the main component of the vapor phase and that $\mathrm{CO}_{2}$ and aliphatics are the main components of the liquid phase. Molecular water is associated in large amounts as an immiscible phase (in current conditions) in the external part.

\subsubsection{Calculation of Molecular Ratios}

We calculated the $\mathrm{CH}_{3} / \mathrm{CH}_{2}$ ratio, the $\mathrm{CO}_{2}$ and the $\mathrm{CH}_{4}$ content (Guilhaumou et al., 1990a, Pironon et al., 2001) from the relative intensities of the absorbance spectra in the range $4000-2000 \mathrm{~cm}^{-1}$ (see details in appendix). Some uncertainties may be due to diffraction effects in the mineral matrix and associated components. Comparison of the measured $\mathrm{CH}_{3} /$ $\mathrm{CH}_{2}$ ratios with those measured in exceptionally large fluid inclusions of known composition analyzed individually after extraction by GCMS, (Guilhaumou et al., 1990 a) allows us to define for the aliphatic parts an equivalent alkane chain length which is relative to the molecular $\mathrm{CH}_{3} / \mathrm{CH}_{2}$ ratio for a given compound. We therefore use an internal calibration curve integrating thus the corrections due to discrepancies previously recognized between fluid inclusions and free oil of same composition (Guilhaumou et al., 1990a; Pironon and Barres., 1990). To account for the specificity of fluid inclusions, the following procedure is applied.

The spectra are recorded systematically in the liquid phase and in some cases after homogenization of all phases at temperature up to $150^{\circ} \mathrm{C}$ (Guilhaumou et al., 2004). The results are given as an equivalent alkane chain length with an error of $\pm 1 \mathrm{C}$ (see details in appendix), a precision suitable to distinguish the main stage of organic matter as classified by Behar et al., (1990) and to calculate isochores for thermodynamic modeling (Mougin, 1999; Guilhaumou et al., 2000). 


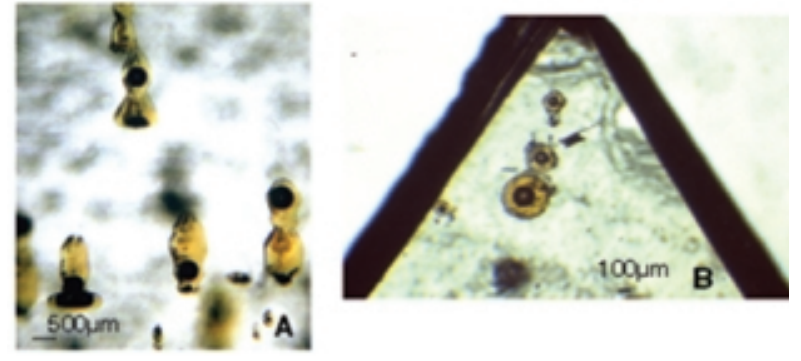

Figure 1

Typical large primary fluid inclusions in Baluchistan (A) and Tunisia (B) from which the GCMS analyses were performed after individual extraction.

The $\mathrm{CO}_{2}$ and $\mathrm{CH}_{4}$ content and, in some cases, a molecular alkane content were calculated using their respective relative IR absorption intensities following the procedure of Pironon et al., 2001.

\section{CASE STUDIES IN SANDSTONES RESERVOIRS: CONSTRAINT FOR SILICEOUS DIAGENESIS}

\subsection{North Sea (Dunbar Area)}

The Brent Province in the North Sea contains the largest hydrocarbon reserves of north western Europe. The reservoirs occur in the Brent group sandstones deposited in the middle Jurassic (Aplin et al., 2000). In some parts of the field, the permeability and porosity have been drastically reduced by intensive siliceous diagenesis associated with clay mineral transformations. Both aqueous and hydrocarbon fluid inclusion are entrapped in significant siliceous overgrowth. The overall composition of the fluid phases during these transformations can be derived from in situ individual fluid inclusion analyses at the microscopic scale. Both types of fluid inclusions (oil and aqueous) were previously studied by UV microscopy and microthermometry in order to determine the trapping temperatures (Cordon and Guilhaumou 1995: Guilhaumou et al., 1998a). Two generations of organic
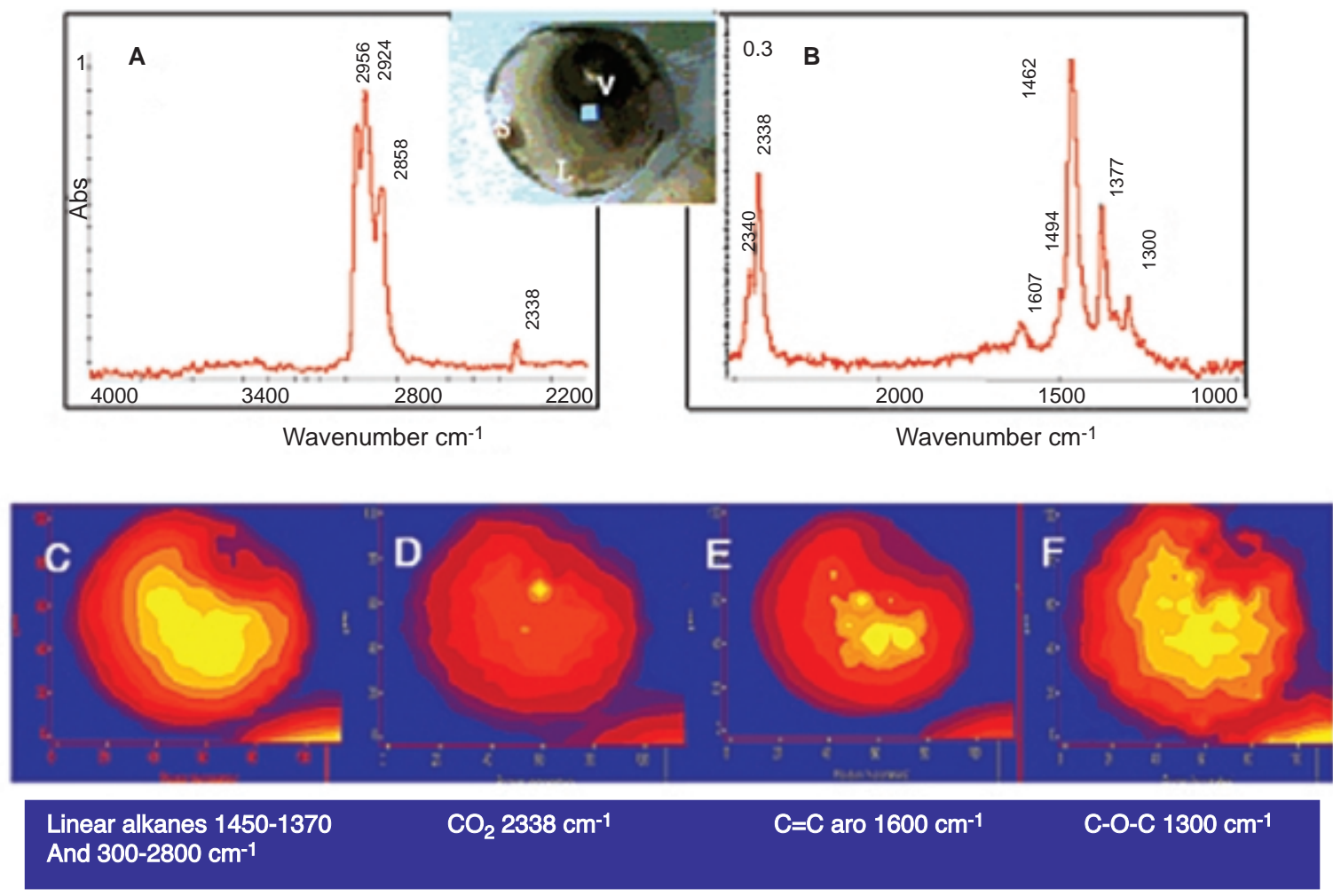

Figure 2

Molecular mapping of the chemical components inside a primary fluid inclusion from Baluchistan.: The spectra in the mid infrared range (4000-1500 $\mathrm{cm}^{-1}$ ) show the distributions of linear alkanes, $\mathrm{CO}_{2}$, aromatic hydrocarbons $\left(1607 \mathrm{~cm}^{-1}\right)$, and additional component (weak band at $1300 \mathrm{~cm}^{-1}$ ); Water is not detected. (see text for explanation). For better representation the results are presented in two parts: spectrum A is recorded in the liquid phase and spectrum $\mathrm{B}$ in the vapor phase where aromatics and additional components are better detected. In vapor (B, spectrum is expanded in absorbance by a factor $\mathrm{x} 3$ ), the $\mathrm{CO}_{2}$ has a double band at 2340 and $2338 \mathrm{~cm}^{-1}$ while in the liquid (A) it has a single one at $2338 \mathrm{~cm}^{-1}$; the aromatic $\mathrm{V}-\mathrm{CH}$ at $3030 \mathrm{~cm}^{-1}$ is not seen because of its weak absorbance compared to alkane stretching. 

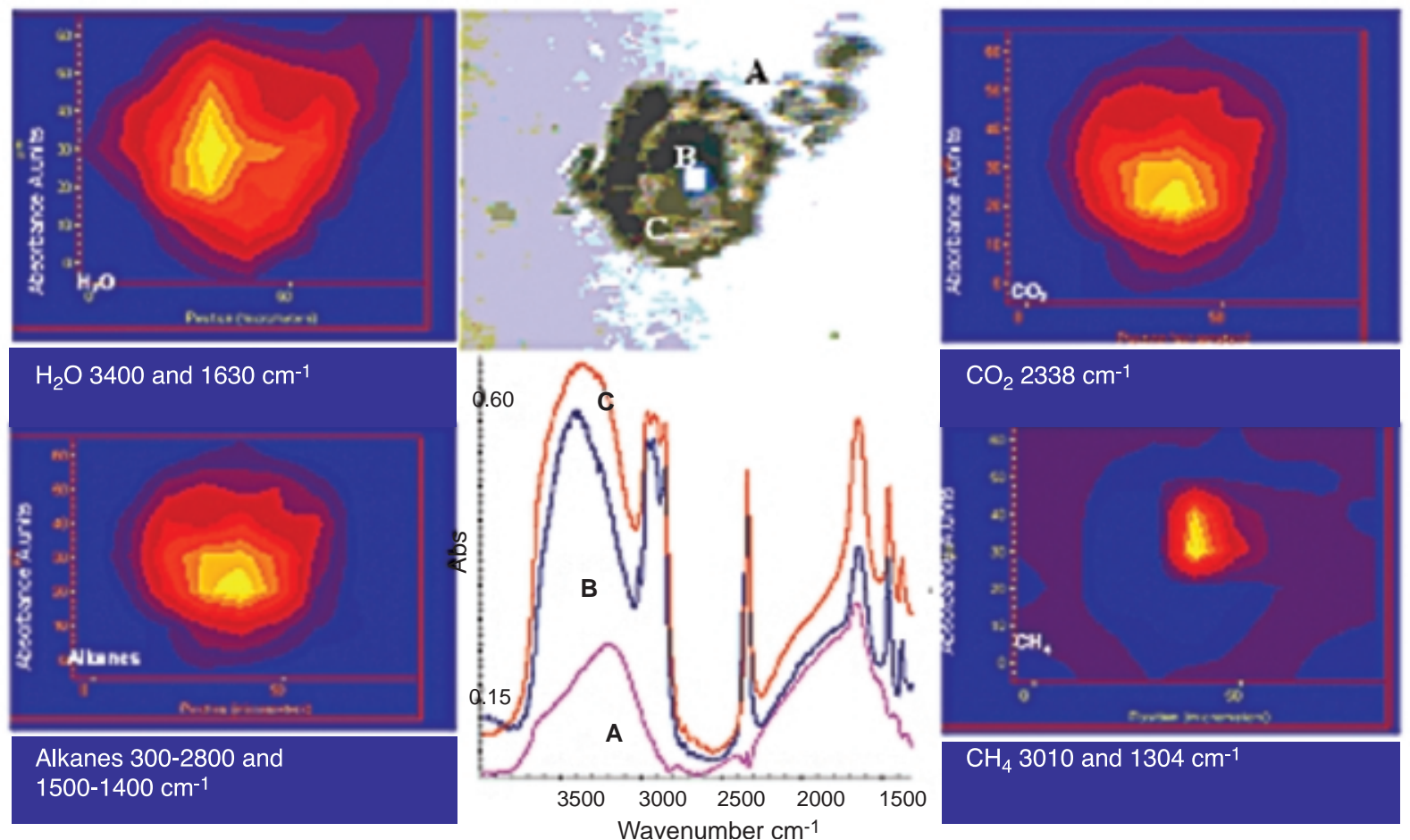

Figure 3

Molecular mapping of a precoceous (primary type) hydrocarbon fluid inclusion content in a sample of fluorite. The spectra in the mid infrared range (4000-1500 $\left.\mathrm{cm}^{-1}\right)$ show the distribution of $\mathrm{CH}_{4}, \mathrm{CO}_{2}$, alkanes and molecular water inside fluid inclusions. See text for explanations.

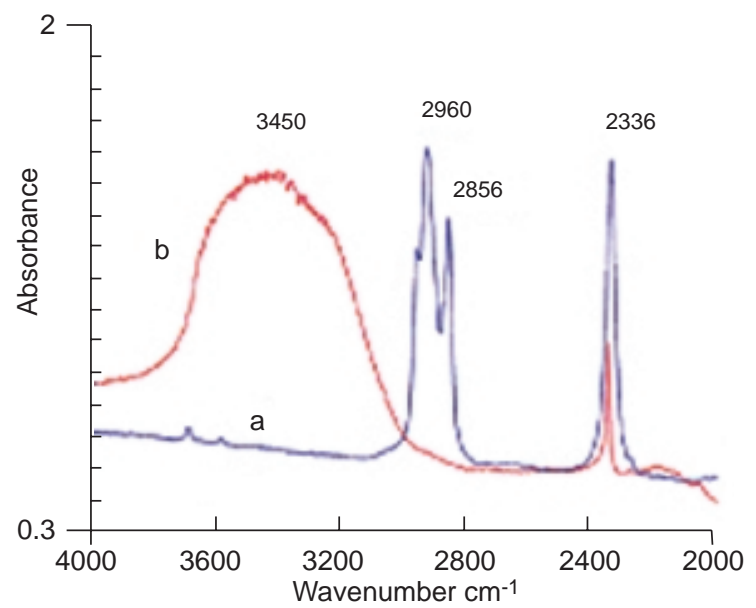

Figure 4

Typical spectra of the two types: a, hydrocarbon (peak at $3000-2800 \mathrm{~cm}^{-1}$ ) and $\mathrm{b}$, aqueous (large band at 3600 $3200 \mathrm{~cm}^{-1}$ ) of small size (less than $10 \mu \mathrm{m}$ ) primary fluid inclusions in diagenetic recristallisations of North sea sandstones (from Guilhaumou et al., 1998). Both types show $\mathrm{CO}_{2}$ as dissolved component (peak near $2340 \mathrm{~cm}^{-1}$ ).

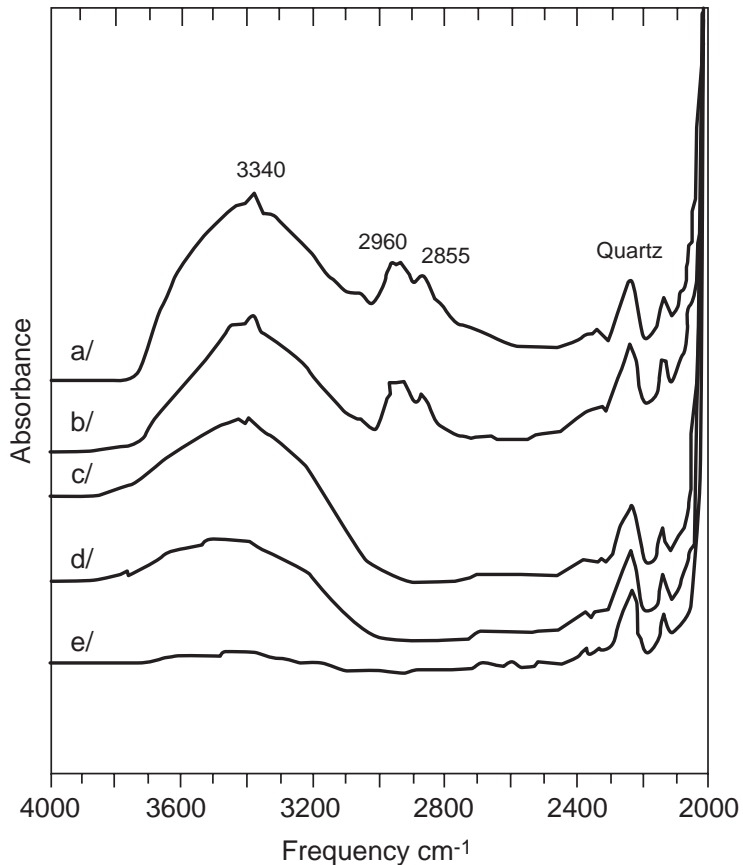

Figure 5

Spectra of first generation of hydrocarbon containing fluid inclusions in North sea sandstones diagenetic recristallisations. 
FI's were described, the first being at the boundary between detrital grains and siliceous overgrowth, the second occuring inside detrital grains. The SR FTIR is able to clearly discriminate, from their typical vibrations (Fig. 4), the aqueous type from hydrocarbon type as well as mixing in various proportions. Figure 5 displays the spectra obtained for four inclusions of the first generation (Fig. 5a to 5d, Guilhaumou et al., $1998 \mathrm{~b}$ ) and a spectrum of the quartz matrix for comparison (Fig. 5e). The main band centred at around $3400 \mathrm{~cm}^{-1}$ is due to molecular water trapped inside the FI, the massif at 2800$3000 \mathrm{~cm}^{-1}$ is assigned to aliphatic stretching vibrations of $\left(\mathrm{CH}_{2}-\mathrm{CH}_{3}\right)$ hydrocarbons and the small band near $3030 \mathrm{~cm}^{-1}$ to aromatics. Results show that the content varies from inclusion to inclusion. $\mathrm{CO}_{2}$ and $\mathrm{CH}_{4}$ are not detected. The calculated chain length using alkane references (Guilhaumou et al., 1990a) is in the range $\mathrm{C}_{6}-\mathrm{C}_{10}$. Figure 6 displays the spectra of three FI's of second generation $(\mathrm{a}, \mathrm{b}, \mathrm{c})$ and the spectra in the quartz matrix for comparison (d). Two types of FI's can be noticed: aliphatic oil containing FI's with a significant amount of dissolved $\mathrm{CO}_{2}$ (band at $2338 \mathrm{~cm}^{-1}$ ) where no water is detected $(a, b)$ and a mixed type with highly variable amount in water and oil containing dissolved $\mathrm{CO}_{2}$ (c). In oil FI's the equivalent chain length is in the range $\mathrm{C}_{8}-\mathrm{C}_{12}$.

Two distinct organic fluid inputs having different maturation levels entered the sandstone reservoir during diagenesis.
The systematic coexistence of oil and aqueous FI's in overgrowth (Guilhaumou et al., 1998b) confirms that basinal fluids and light hydrocarbons depleted in $\mathrm{CO}_{2}$ were both present when silicification began. Thus hydrocarbon migration had already started. The hydrocarbons were present as an immiscible phase at the time of entrapment. A second generation of more evolved hydrocarbon (higher chain length) FI containing dissolved $\mathrm{CO}_{2}$ and various amounts of water entered the fracture after the main diagenetic episode. The heterogeneity of trapping for the two generations of oil FI preclude calculation of the precise P-T conditions using microthermometric measurements of both aqueous and oil FI's.

\subsection{Sub Andean Basins (Eastern Venezuela, Colombian Foothills)}

Over the last ten years, after the discoveries of the El Furrial and Cusiana fields, petroleum exploration has drastically increased in the foothills areas of Venezuela and Colombia. In such complex zones major exploration risks include damage to porosity and permeability by intense fluid circulations during thrust loading and tectonic deformation. In Venezuelan sandstones two onsets of hydrocarbon fluid inclusions were again found in detrital grains and calcite cements of the El Furrial Oligocene reservoir.

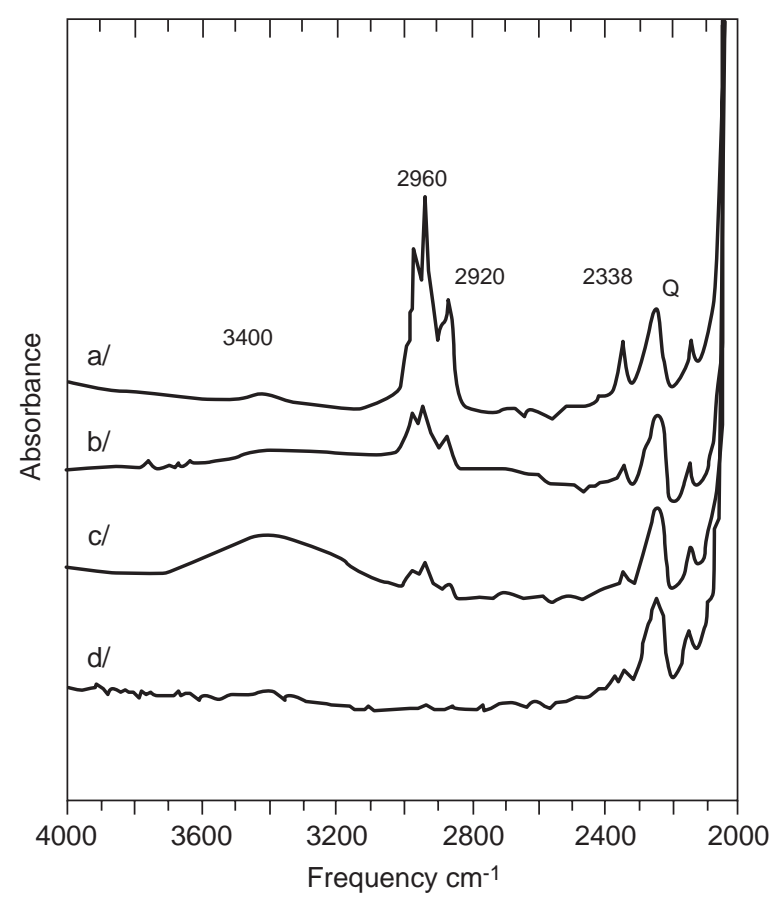

Figure 6

Spectra of secondary oil containing fluid inclusions in fractures of North sea sandstones diagenetic recristallisations.

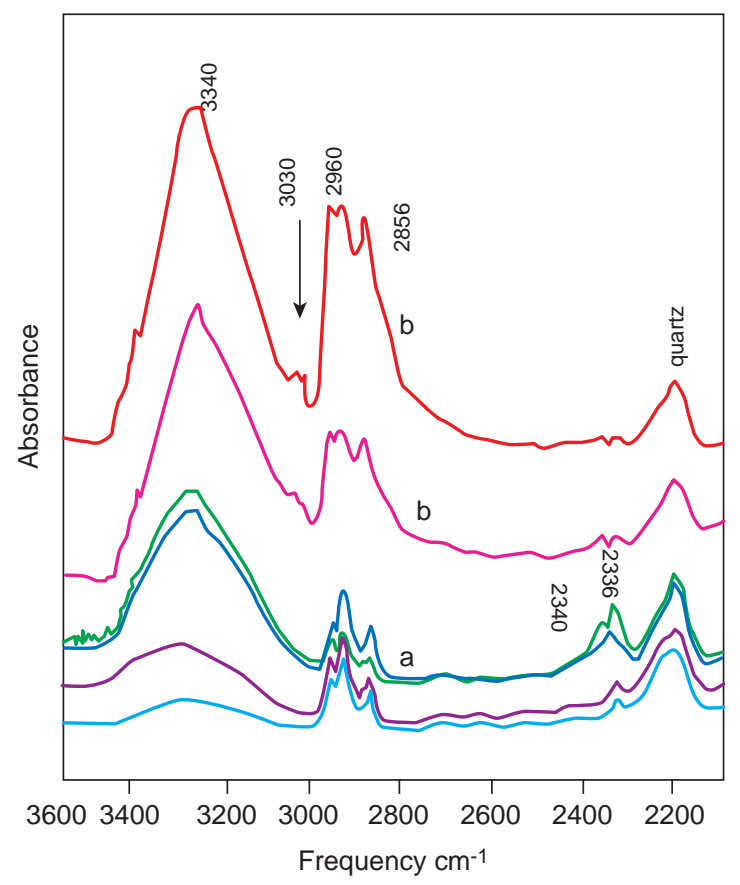

Figure 7

Typical spectra of the two distinct generations of hydrocarbon containing fluid inclusions in Venezuelian sandstones. a) aliphatic hydrocarbons in $\mathrm{C}_{7}-\mathrm{C}_{9}$; b) hydrocarbons with shorter chain length and a high aromatic fraction indicated by the vibration at $3020-3030 \mathrm{~cm}^{-1}$. 
Organic fluid inclusions of the first population are yellow-brown in colour and are included in quartz overgrowth. Ten to twenty inclusions of each sample have been analysed in the two formations. The characteristic stretching vibrations of aliphatics and a very strong band corresponding to molecular water are observed (Figure 7 a). A narrow small band at $2337 \mathrm{~cm}^{-1}$ is due to dissolved $\mathrm{CO}_{2}$. The relative intensity of $\mathrm{CH}_{2}$ and $\mathrm{CH}_{3}$ stretch modes indicates a short chain length, in the range $\mathrm{C}_{7}-\mathrm{C}_{9}$. Note that $\mathrm{CH}_{4}$ is not detected (absence of the characteristic vibrational feature at $\left.3010 \mathrm{~cm}^{-1}\right)$. The second population (Fig. 7 b) shows a strong absorption in the aromatic stretching region with two peaks at 3040 and $3070 \mathrm{~cm}^{-1}$. Dissolved $\mathrm{CO}_{2}$ is not detected. The intensity of the bands in the $3000-2850 \mathrm{~cm}^{-1}$ range, corresponding to $\mathrm{CH}_{2}$ aliphatic stretching mode, is very weak and indicates that the chain length should be shorter. These results allow two organic components entrapped during oil migration to be differentiated, indicating two very different stages of oil maturation. There is a high variability of fluid inclusion content (water, liquid and hydrocarbon). This could explain the large range of homogenisation temperatures measured by microthermometry ( 95 to $150^{\circ} \mathrm{C}$ ). We also detect a signal characteristic of aliphatic compounds in some areas surrounding the precocious aqueous fluid inclusions in quartz. These results linked to petrographic observations suggest that the oil refilled old cavities after the quartz cementations.

The organic part of those fluid inclusions was affected by high temperature during further tectonic evolution and evolved towards a more aromatic structure. The present day temperature in El Furrial $\left(160^{\circ} \mathrm{C}\right)$ is higher that at the time of cementation, occurring near $90^{\circ} \mathrm{C}$ (homogenisation temperature of aqueous fluid inclusions in cements corresponding to the main episode of sedimentary burial in the foredeep). Thus it might be concluded that early cementation and hydrocarbon input prevented new fluid entering the structure during burial and further tectonic evolution (Roure et al., 2004, 2005).

\section{INTEGRATED APPROACH FOR BASIN MODELING: VALIDATION ON TWO CASE STUDIES (TUNISIA AND PAKISTAN)}

Reconstructions of the burial and thermal history provide the key to predict the timing of petroleum generation. However, another critical parameter that needs to be better controlled for an accurate reservoir appraisal is the paleo-pore fluid pressure. A new approach based on FTIR in situ microanalysis of hydrocarbon fluid inclusions, PVT modeling of the entrapped hydrocarbon and microthermometry of the whole set of contemporaneous fluid inclusions has been tested and is validated here, based on two case studies in Koh-i-Maran (North Kirthar range, Pakistan) and Hammam Zriba, (Zaghouan Province, Tunisia).

In these two areas, fluorite ore deposits occur at or near a regional unconformity that developed at the base of the Cretaceous series, between a late Jurassic carbonate reservoir and overlying late Cretaceous seals. Because of these particular stratigraphic relationships, previous authors proposed that these ore deposits were coeval with subaerial karstification developed during Cretaceous emersion of the Jurassic limestones. However, such a scenario is unlikely as, in these fluorite deposits, aqueous fluid inclusions always display quite elevated trapping temperatures (Bouhlel et al., 1988; Guilhaumou, 1989; Guilhaumou et al., 2000). The thermalbarometric modeling presented here provides further evidence for a Cenozoic age for hydrothermal karstification in both areas, which indeed accounts for the observed mineralisation.

Microthermometric analyses were first carried out to determine the overall composition (Guilhaumou, 1989) of aqueous mineralising fluids and the homogenization temperatures of both aqueous and hydrocarbon fluid inclusions. The origin and P-T conditions of reservoir cementation in both Pakistan and Tunisia were previously discussed in Bouhlel et al., 1988; Rankin et al., 1990; Guilhaumou et al., 2000).

\subsection{Composition of the Hydrocarbon Fluid Inclusions}

\subsubsection{Koh-i-Maran ore Deposit}

In fluorite samples, the primary hydrocarbon FI's range in size between $100 \mu \mathrm{m}$ and $1 \mathrm{~mm}$, are often associated with aqueous fluids (Fig. 3A, Rankin et al., 1990; Guilhaumou et al., 2000). Inclusions contain a vapor bubble and often several brown and birefringent bituminous solid bodies, products of the in situ evolution of the trapped organic matter (Richardson and Pinckney, 1984). Microfluorometric measurements have shown two hydrocarbon fluid generations entrapped in fluorite minerals (Guilhaumou et al., 1990). The first type of hydrocarbon fluid is luminescent in the pale blue region, while the second type yields a brown-yellow fluorescence. Results here concern the first type which represents the fluid occurring during main fluorite crystallization.

The equivalent chain length of $n$-alkanes calculated from FTIR analyses (Fig. 2) is $\mathrm{C}_{8}$ to $\mathrm{C}_{12}$. $\mathrm{CO}_{2}$ is a major component dissolved in the liquid phase and in the vapor phase, the aliphatics and aromatics may coexist with alkyl $\mathrm{NO}_{2}$ ? (shoulder at $1494 \mathrm{~cm}^{-1}$ ) in all parts. $\mathrm{CH}_{4}$ is present at low levels, while water is either absent or restricted to the inclusion walls.

The unusually large size of some hydrocarbon fluid inclusions (up to $1 \mathrm{~mm}$, Fig. 1A) in this sample makes it possible to perform individual extraction of oil. The GC-MS analyses reveal light oils, associated with aromatic and aliphatic components with a distribution in length from $\mathrm{C}_{8}$ to $\mathrm{C}_{35}$. $\mathrm{C}_{14}$ is the most abundant component. An equivalent chain length of $\mathrm{C}_{10}$ (Guilhaumou et al., 1990a) is calculated. This value agrees with that previously calculated from FTIR spectroscopy. The occurrence of bio-markers such as terpane in the FI indicates a carbonated source-rock which was deposited in hypersaline and/or anoxic confined environment (Ellouz et al., 1995; Guilhaumou et al., 2000). 


\subsubsection{Hammam Zriba Deposit}

Large-sized primary fluid inclusions were analysed in the geodic fluorite from Hammam Zriba (Tunisia, Bouhlel et al.,1988; Guilhaumou et al., 1988; 1990b). FTIR spectra indicate the presence of aliphatic components associated with $\mathrm{CO}_{2}$ and $\mathrm{H}_{2} \mathrm{O}$ in the liquid and vapor phases. Some $\mathrm{CH}_{4}$ was also detected. FTIR microspectrometry mapping, performed by Synchrotron FTIR (Fig. 3) confirms the presence of large proportions of $\mathrm{CH}_{4}$ mainly in the vapor phase and of $\mathrm{CO}_{2}$ associated mainly with aliphatic hydrocarbons. Aromatics contents are low. Water is associated as a heterogeneous phase in highly variable amounts. The GC-MS analysis of extracts reveals light oils in the $\mathrm{C}_{6}$ to $\mathrm{C}_{25}$ range, an equivalent chain length of $\mathrm{C}_{10}$ is calculated. This value agrees with the value of $\mathrm{C}_{9}$ previously calculated from FTIR spectroscopy, considering that during extraction (see appendix) we loose a part of the light fraction (Guilhaumou et al., 1990 a). Semi quantitative measurements using the Beer-Lambert law and an internal $\mathrm{CH}_{4}$ calibration following the procedure of Pironon et al., (2001) lead to 42 mole percent $\mathrm{CH}_{4}$ and 5 mole percent $\mathrm{CO}_{2}$ as additional components.

\subsection{Pressure Temperatures of Trapping}

Liquid vapor curves and isochors were calculated for the compositions defined in these fluid inclusions by PVTX modeling (details in Guilhaumou et al., 2000) using a modified Equation of State (EQS) with a software developed at IFP by P. Mougin. (1999) using the hydrocarbon data base of Montel (1993). We calibrated the software from experimental data (Ellouz et al., 1995; Guilhaumou et al., 1990 a, 2000) and optimized the three control parameters $\alpha, \beta$ and the $\mathrm{CO}_{2}$ mole fraction to derive the possible liquid-vapor phase envelopes associated with their isochores in P-T diagram for each set of samples.

For the fluorite from Koh-i-Maran, (Guilhaumou et al., 2000; Benchilla 2003, et al., 2003) the $\alpha$ value of 0.88 calculated from composition measured by FTIR is close to the $\alpha$ value of 0.9 deduced from gas chromatographic analysis, which validates the results of the PVTX modeling. In the monophasic domain the slope value $\left(\mathrm{K}_{\mathrm{Hc}}\right)$ of the hydrocarbon isochore is $0.33^{\circ} \mathrm{C} . \mathrm{bar}^{-1}$, the slope value of the water isochore $\left(\mathrm{K}_{\mathrm{w}}\right)$ being $0.08^{\circ} \mathrm{C} \mathrm{bar}^{-1}$, The trapping pressure, obtained by crosscutting isochores following the procedure shown in Figure 8, has an average value of 200 bars, corresponding to a maximum depth of $2000 \mathrm{~m}$ for a hydrostatic pressure gradient of 0.1 bars. $\mathrm{m}^{-1}$. The trapping temperature is around $125-130^{\circ} \mathrm{C}$.

For the fluorite sample from Hammam Zriba, the $\alpha$ value calculated from composition measured by FTIR is also similar to the $\alpha$ value deduced from gas chromatograhic analyses $(\alpha=0.95)$, which again allows us to validate the PVTX modeling. In the monophasic domain the slope value $\left(\mathrm{K}_{\mathrm{Hc}}\right)$ of the hydrocarbon isochor is $0.29^{\circ} \mathrm{C} \cdot \mathrm{bar}^{-1}$, which is coherent with the previous estimates obtained by Guilhaumou (1988). The slope value of the salt water isochor $\left(\mathrm{K}_{\mathrm{w}}\right)$ is $0.09{ }^{\circ} \mathrm{C}$. bar $^{-1}$ (Roedder, 1981, 1984). The trapping pressure is centered at $115 \pm 2$ bars and at temperatures around $130^{\circ} \mathrm{C}$.

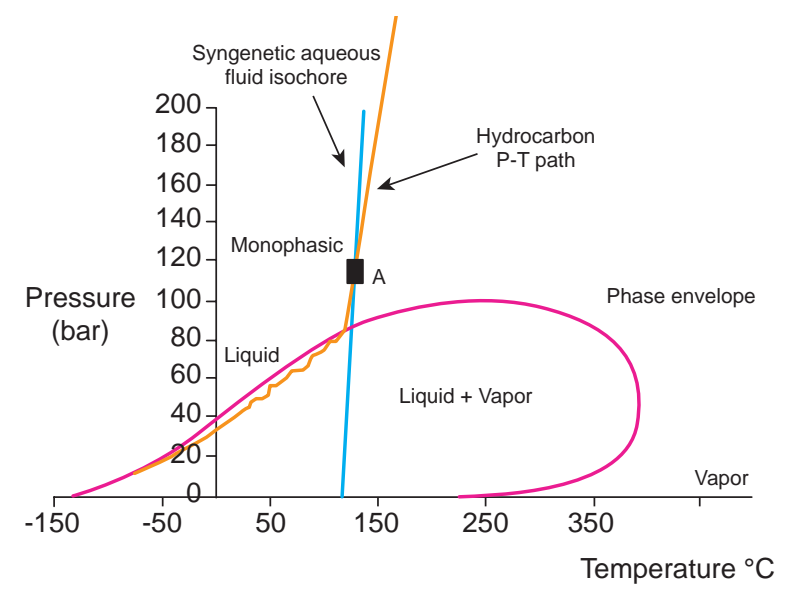

Figure 8

Determination of the pressure and temperature of trapping: the liquid vapor curve and isochors are calculated from the in situ composition of the hydrocarbon fluid inclusion analyzed by FTIR. The crosscut of hydrocarbon FI isochores and aqueous FI isochores initiated at homogenization temperatures on the liquid vapor curves lead to define the entrapped temperature and pressure for the fluid circulation.

\section{Integration in Geological Modeling}

The THRUSTPACK 2D forward kinematic modeling software (Sassi and Rudkiewicz, 1996, 2000) has been used to reconstruct the kinematic and thermal evolution of the Zaghouan and Koh-i-Maran foothills. Burial curves and temperature values computed for the host rocks have been compared with PVTX data derived from fluid inclusions entrapped within the fluorite cements, in order to determine the true PT conditions of reservoir cementation. This helped to determine whether the mineralising fluid was at thermal equilibrium with the host-rock (the thermal transfers being then essentially conductive), or if circulation of deep fluids along fractures could have been fast enough to preserve a thermal disequilibrium with the host-rock for a long time, due to heat supply by advecting hot fluids. This integration of fluid inclusion data into the regional geodynamic evolution finally allows dating of mineralisation at both Koh-i-Maran and Hammam Zriba Guebli (Benchilla 2000, Benchilla et al., 2003). In the Koh-i-Maran area (Fig. 9), the initial stage of mineralization started during the lower Oligocene and 
involved deep fluids circulating horizontally along the decollement and are in thermal equilibrium with the Jurassic host reservoir. In Hammam Zriba Guebli (Fig. 10) the mineralization is related to vertical migration of hot hydrothermal fluids with hydrocarbons rising quickly from the underlying Triassic series along border faults of horst and Grabens from Tortonian times onward.

\section{CONDITIONS OF CARBONACEOUS DIAGENESIS IN EOCENE CHORGALI FORMATION (POTWAR BASIN, NORTHERN PAKISTAN).}

\subsection{Summary of Diagenetic Events}

Shallow-marine carbonate strata of the Eocene Chorgali Formation form an important hydrocarbon producing horizon in the northern part of the Potwar Basin (N-Pakistan, Moshin et al.,1983). Based on a limited number of core samples from the Dakhni gas-condensate field and on data gathered from an outcrop analogue located at Chorgali Pass, north of this producing field, the sedimentary, early diagenetic and fracture-related characteristics of this dual porosity reservoir were studied and compared with fold-and-thrust belt evolution in Benchilla (2003).

The late diagenesis is mainly characterised by (hydro) fracturation in which at least seven distinct fracturation episodes were recognised. Based on luminescence characteristics and stable isotope studies, late stage cements may reflect TSR conditions. Authigenic quartz developed in these hydroveins during the Mesogenesis. These quartz are surprisingly rich in primary hydrocarbon fluid inclusions also found in associated calcite.

\subsection{Fluid Inclusions Data}

Two generations of fluid inclusions containing hydrocarbons are identified. First are primary exceptionally large sized cavities in the centre of the crystals, second are small sized elongated shape cavities along crystal growth on the external parts of the crystals (Fig. 11).
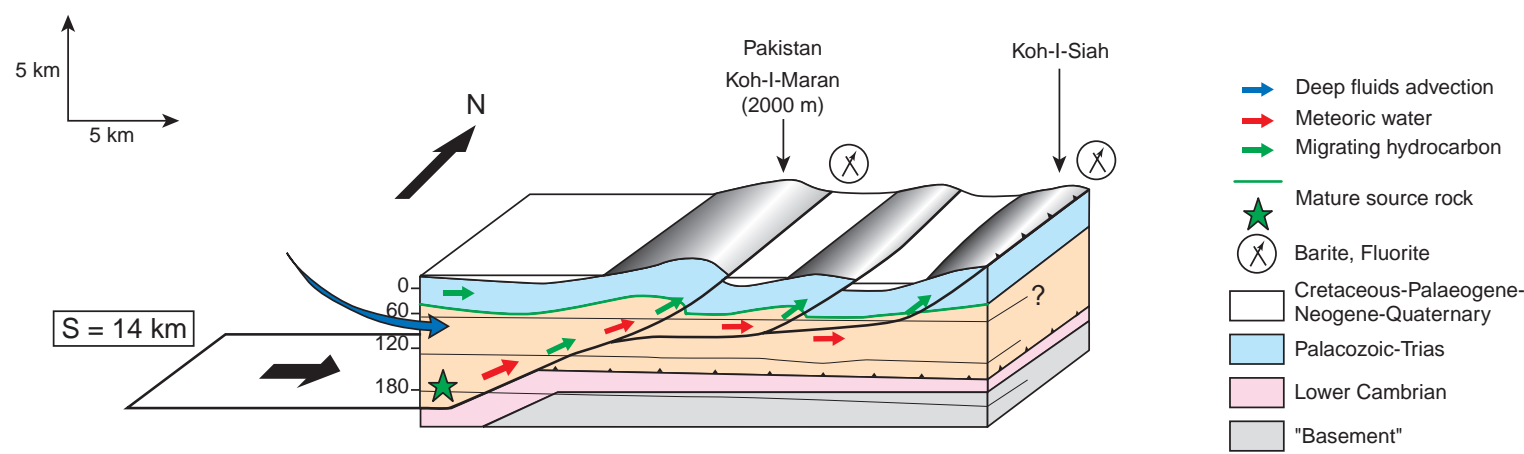

Figure 9

Example of the reconstitution of the fluid circulations in the foothills area of Koh-i-Maran, Baluchistan from Benchilla et al., 2003.

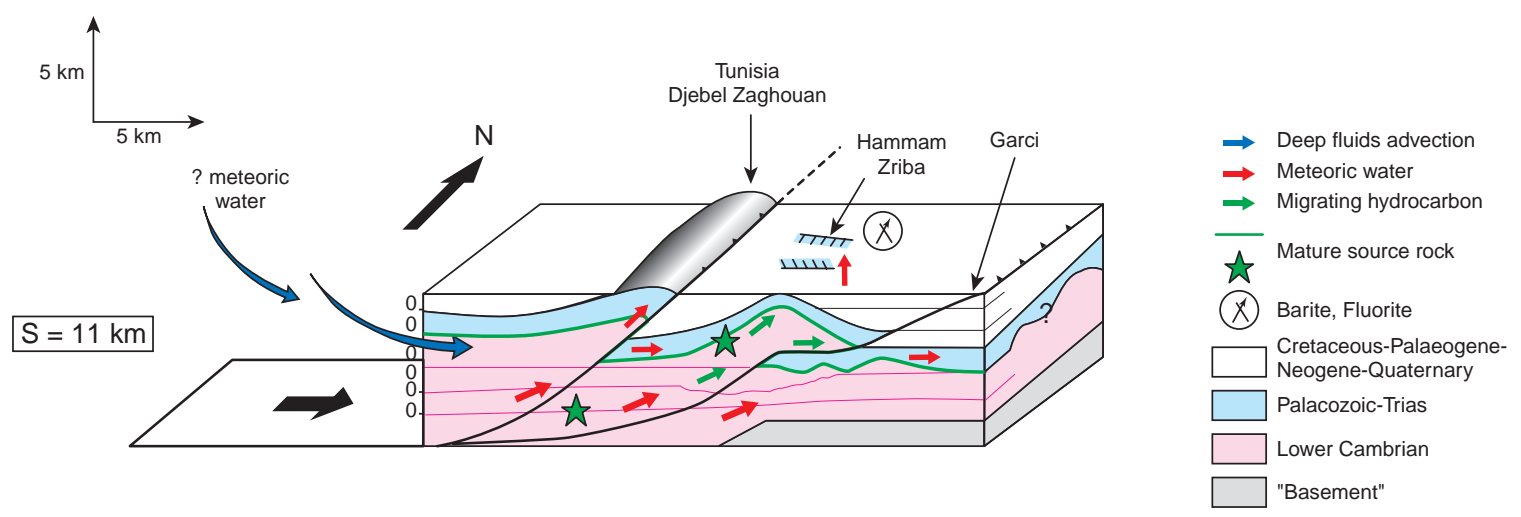

Figure 10

Example of the reconstitution of the fluid circulations in the Hammam Zriba Guebli ore deposit. from Benchilla et al., 2003. 

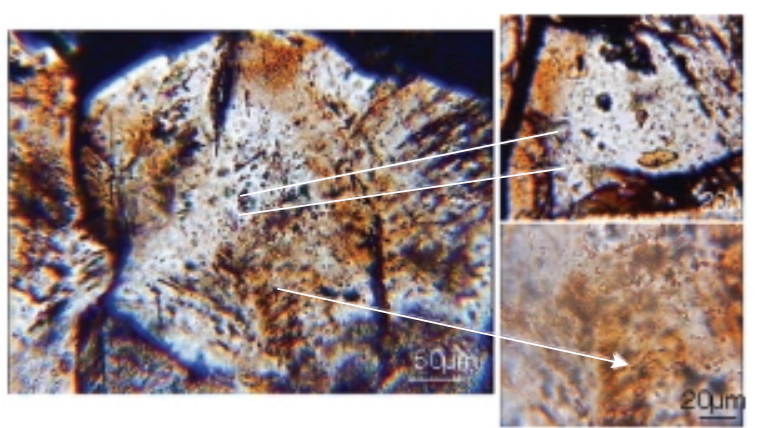

Figure 11

Example of primary and pseudosecondary hydrocarbon containing fluid inclusions in an authigenic quartz from the Chorgali area.

\subsubsection{Primary Oil FI in Authigenic Quartz and Calcite}

The absorbance spectra along profiles through primary oil FI in diagenetic quartz (Fig. 12 part 2) show the characteristics of the early petroleum generation. These FI's are mainly composed of linear alkanes which are detected in the whole cavity by their absorption at $3000-2800 \mathrm{~cm}^{-1}$. They have a high $\mathrm{CO}_{2}$ content, now occurring as a phase dissolved in the alkane fraction (absorption at $2336 \mathrm{~cm}^{-1}$ ), whereas aromatics are not detected. Absorbance of molecular water is low although $\mathrm{OH}$ groups were detected in the surrounding quartz (typical absorbance at $3380 \mathrm{~cm}^{-1}$ ). Semi quantitative analyses, using an internal $\mathrm{CH}_{4}$ calibration and following the procedure of Pironon et al., (2001) have been performed on several primary FI's, in five different quartz crystals. They lead to the identification of a typical composition of aliphatic light oil in the $\mathrm{C}_{10}-\mathrm{C}_{12}$ range, with average content of $30 \%$ $\mathrm{CH}_{4}, 1 \% \mathrm{CO}_{2}$ and very little molecular water. The microanalyses of more than twenty primary FI's show that this oil was entrapped homogeneously at the beginning of the crystal growth (Table 1).

In some of these FI's, very small crystals, with sizes comprised between 1 and $6 \mu \mathrm{m}$, are dispersed in oil (Fig.14). These crystals show an additional absorption at $2520 \mathrm{~cm}^{-1}$ which is unambiguously attributed to the $\mathrm{CO}_{3}{ }^{2-}$ bonds and allows identification of these solid phases as carbonates (Farmer, 1974, Salisbury et al., 1992). The comparison with some spectra recorded from calcite hosted in quartz show that they are probably small seeds of calcite minerals. Experiments were performed by heating this type of FI using a microthermometic stage from room temperature to homogenization temperature under the Synchrotron IR beam. Some spectra

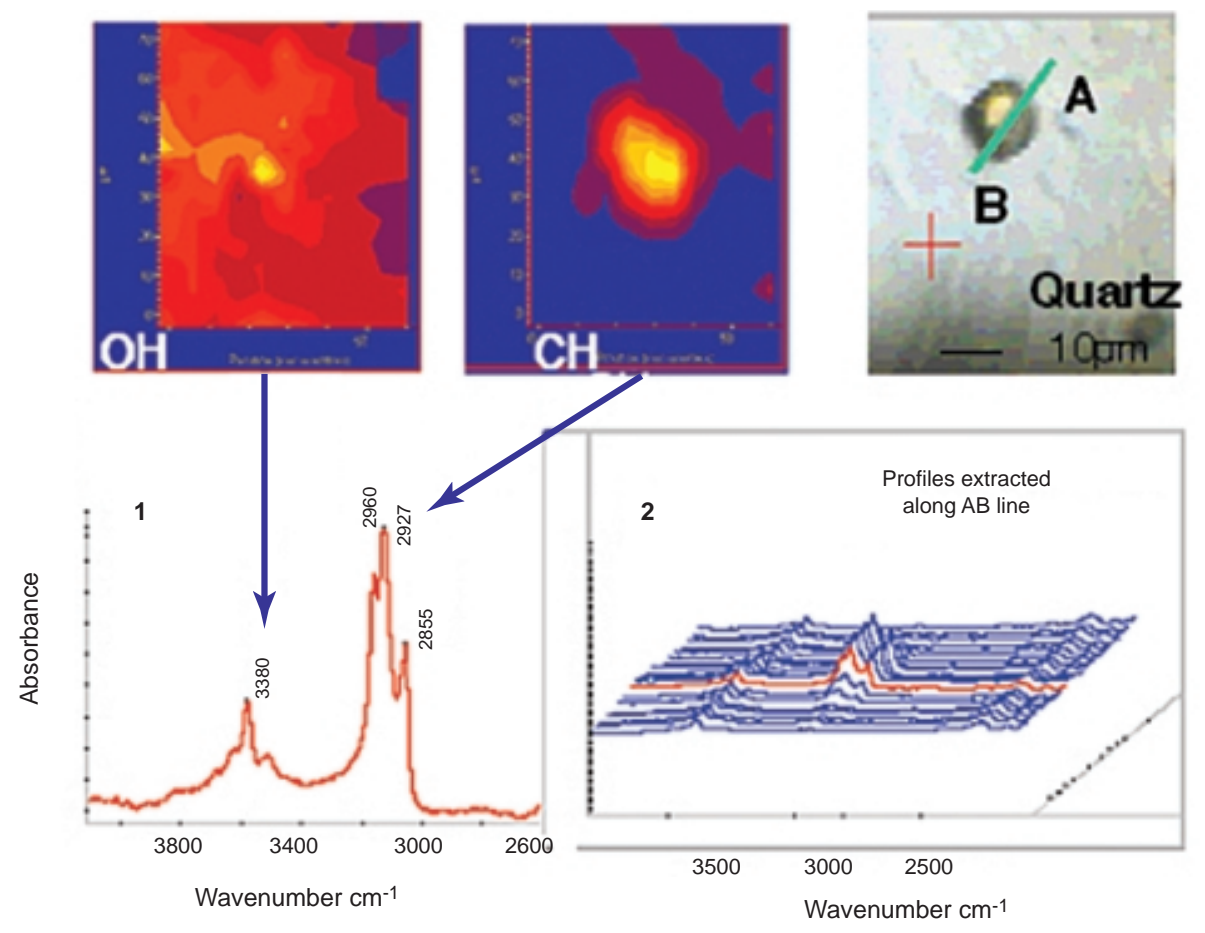

Figure 12

Distribution of $\mathrm{OH}$ in quartz matrix around a hydrocarbon fluid inclusion. Mapping shows that $\mathrm{OH}$ are distributed in quartz around the Hydrocarbon inclusions (typical absorption at $3380 \mathrm{~cm}^{-1}$ ). This water was probably incorporated during quartz crystallization. It did not seem to originate in the fluid inclusion by diffusion process or leakage. The composition calculated from FTIR spectra is: Alkane chain length in the range $\mathrm{C}_{9}-\mathrm{C}_{10}, \mathrm{CH}_{4} 30 \mathrm{~mol} \%, \mathrm{CO}_{2} 1 \mathrm{~mol} \%$. 
recorded on the same point show the slow decrease of the $\mathrm{CO}_{3}{ }^{2-}$ absorption until complete disappearance at homogenization temperature (Fig. 13), and its subsequent reappearance on decreasing the temperature. This allows these carbonates to be identified as calcite daughter minerals.

The FTIR microanalysis of another large hydrocarbon FI (Fig. 14) reveals an exceptional assemblage of minerals entrapped within oil as a key point for diagenesis reconstruction. A rounded highly pleochroic sulfate crystal A (polarized light) similar to some observed inside quartz, occurs close to a small crystal B in the center of the FI. Crystal A has a high absorption in the $\mathrm{OH}$ area with a main band near $3620 \mathrm{~cm}^{-1}$. This suggests that this mineral is a partly dissolved crystal of hydrated sulfate that could be the hemi hydrate calcium sulfate (Mandal and Mandal, 2002). Crystal B shows an absorption near $2520 \mathrm{~cm}^{-1}$ typical of carbonate micro crystals (Legodi et al., 2001). Some polarizing minerals 5 to $20 \mu$ in size are also identified as carbonates, they occur at the interface between quartz and oil in those FI types. This assemblage could represent the typical replacement of hydrated calcium sulfates (as gypsum/anhydrite?) by calcium carbonate as calcite, the reaction being fossilised due to the formation of primary defects containing oil FI's in authigenic quartz.

\subsubsection{Pseudosecondary Oil FI in Quartz}

The SFTIR analyses of the oil FI of the second generation (Fig. 15) indicate a water oil mixture depleted in $\mathrm{CO}_{2}$ (not detected). Molecular mapping shows that the trapping is homogeneous between inclusions, along crystals growth zones. In particular, the oil phase appears always associated with a noticeable water phase. The high detection level of FTIR suggests that the water is not the dominant phase but is just wetting the walls of the cavities. Therefore such low quantities allow water to be dissolved in oil at least partly during the migration. Quantitative estimates lead to a more mature hydrocarbon in the range $\mathrm{C}_{15}-\mathrm{C}_{17}$ with a high $\mathrm{CH}_{4}$ content, reaching $60 \%$ (Table 1). These compositions would indicate a more mature and /or partly degraded oil consistent with the difference in color (shifted to the red region) observed in the fluorescence emission under UV light (Korashani, 1986; Guilhaumou et al., 1990b).

\subsection{Interpretation}

The most relevant result concerning this diagenetic evolution is the in situ microanalysis of authigenic carbonates closely associated with partly dissolved hydrated sulfates inside hydrocarbon fluid inclusions in diagenetic quartz. This

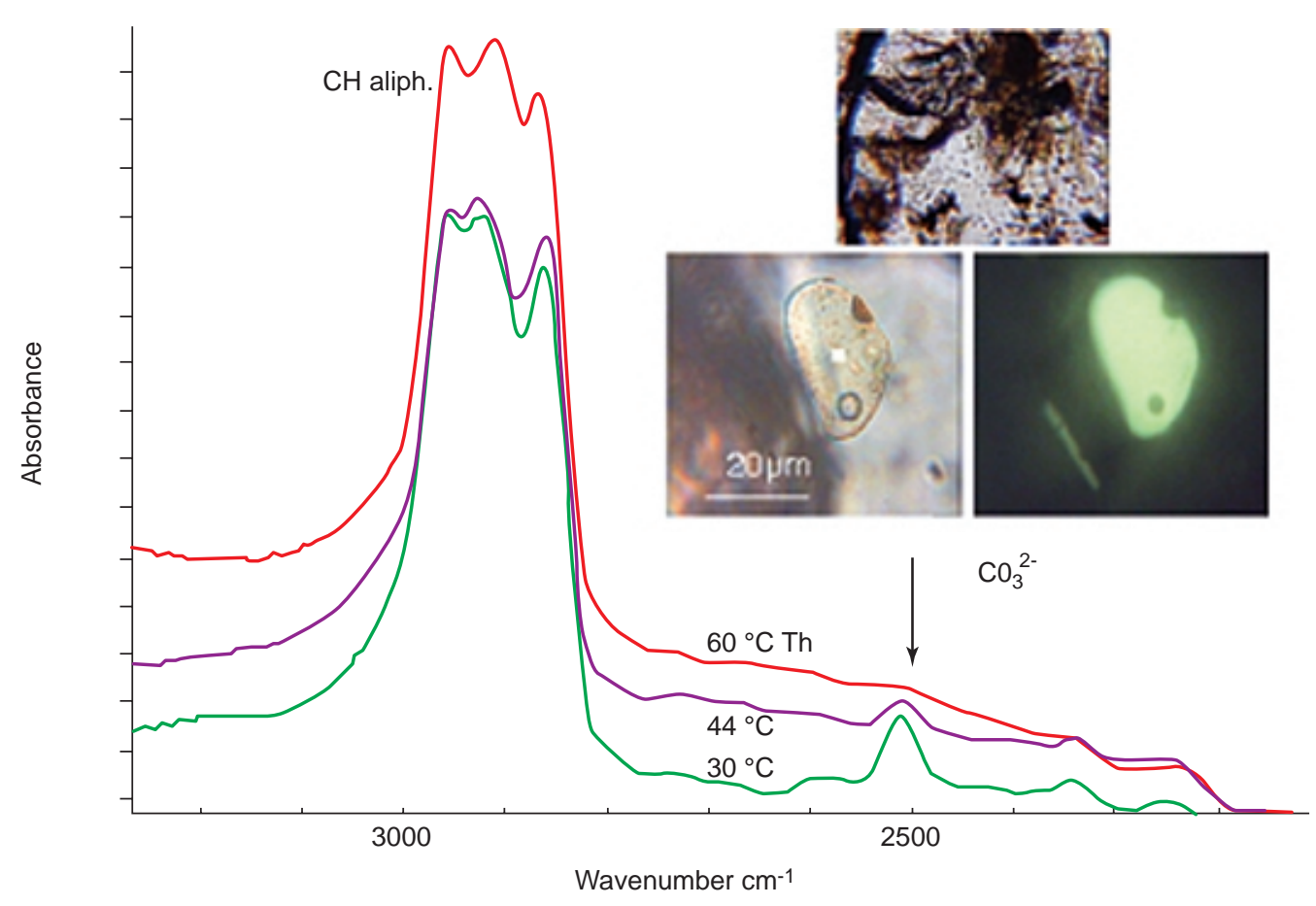

Figure 13

Modification of the spectra during heating experiments: when focussing on the small solid phases inside oil containing fluid inclusion, the carbonate $\left(\mathrm{CO}_{3}{ }^{2-}\right.$ absorption $\left.2520 \mathrm{~cm}^{-1}\right)$ dissapeared slowly on heating. It reappeared at the same point during cooling. 
TABLE 1

\begin{tabular}{|c|c|c|c|c|c|c|c|c|c|c|}
\hline \multirow[b]{2}{*}{ Reference } & \multicolumn{7}{|c|}{ Primary } & \multicolumn{3}{|c|}{ Pseudo secondary } \\
\hline & A1 (6) & A2 (8) & Q12 (6) & Q6 (5) & Q5P (5) & IF3 Ca(5) & Q 18 (6) & IF4 S1 & IF5 S2 & IF6 S3 \\
\hline $\mathrm{S} \mathrm{H}_{2} \mathrm{O}$ & 0 & 0 & 0 & 0 & 0 & 0 & 0 & ++ & ++ & ++ \\
\hline $\mathrm{S} 1 \mathrm{CH}_{3} / \mathrm{CH}_{2}$ & 0.65 & 0.57 & 0.69 & 0.70 & 0.70 & 0.81 & 0.58 & 0.61 & 0.61 & 0.63 \\
\hline $\mathrm{S} 2 \mathrm{CH}_{2} / \mathrm{CH}_{3}$ & 1.54 & 1.74 & 1.45 & 1.43 & 1.43 & 1.24 & 1.72 & 1.65 & 1.64 & 1.57 \\
\hline $\mathrm{S} \mathrm{CH}_{4} / \mathrm{Salk}$ & 0.11 & 0.07 & 0.09 & 0.08 & 0.09 & 0.14 & 0.09 & 0.29 & 0.31 & 0.32 \\
\hline chain length equ. & $\mathrm{C} 10$ & $\mathrm{C} 10$ & $\mathrm{C} 10-\mathrm{C} 12$ & $\mathrm{C} 12$ & $\mathrm{C} 12$ & $\mathrm{C} 10$ & $\mathrm{C} 12$ & C17-C19 & C17-C19 & C17-C19 \\
\hline $\mathrm{CH}_{4}$ mole $\%$ & 37.33 & 30.36 & 33.00 & 30.00 & 31.00 & 41.00 & 34.00 & 62.61 & 64.13 & 63.29 \\
\hline $\mathrm{CO}_{2}$ mole $\%$ & 0.09 & 1.29 & 0.00 & 3.10 & 5.00 & 0.50 & 2.22 & 0 & 0 & 0 \\
\hline
\end{tabular}

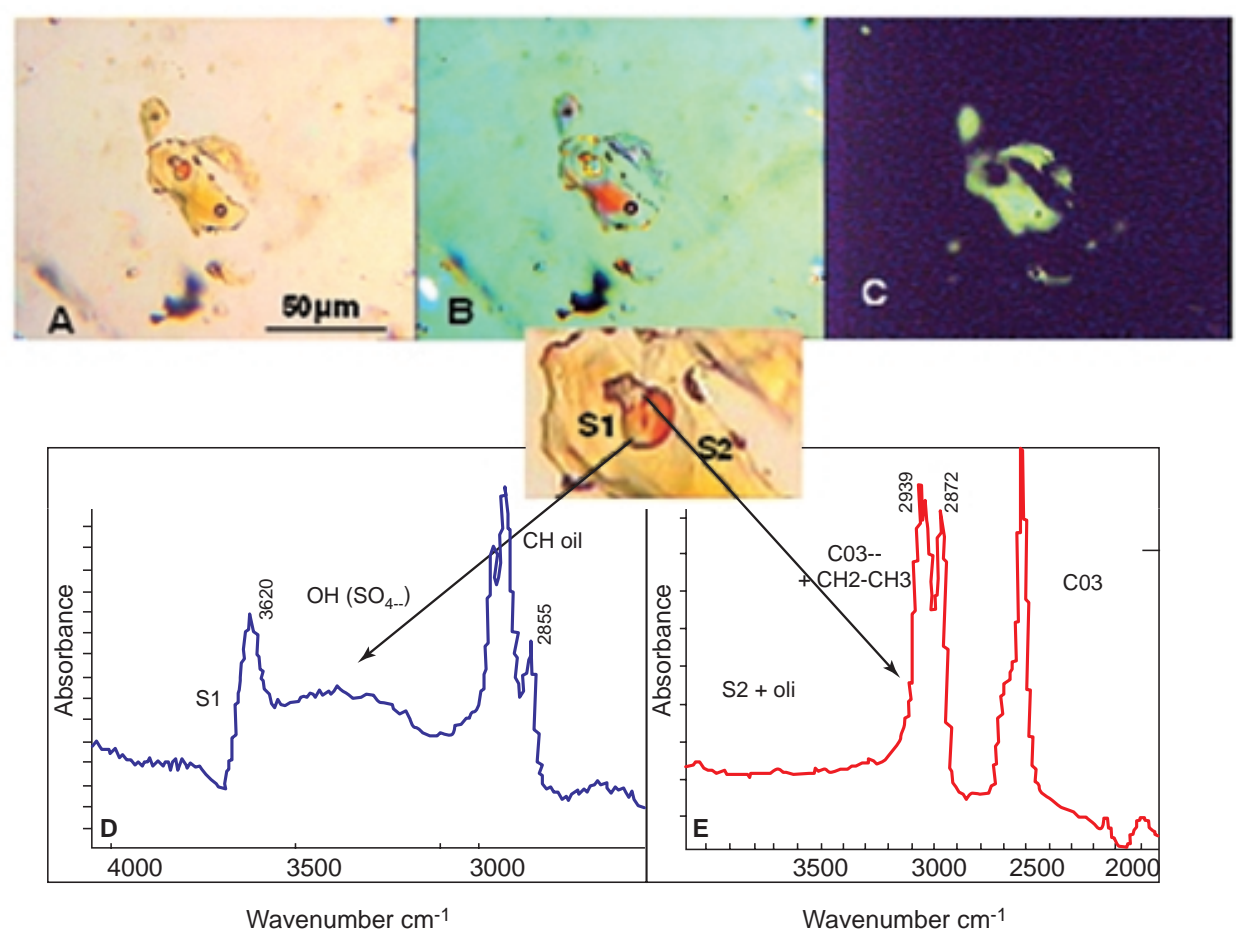

Figure 14

Primary oil fluid inclusion within typical association of entrapped solid phases. A, B, and C, microphotographs in transmitted light, polarized light and UV fluorescence. D and E, punctual FTIR spectra of the solids S1 and S2 in oil phase. Absorptions are characteristic of a sulfate hydrated mineral, like hemihydrate (Mandal et Mandal, 2002) for the solid S1, spectrum D, and of carbonates for the solid S2, spectrum E. The 3000-2800 range show typical absorptions of alkanes which in the case of carbonates (spectrum E) is composed by the addition of $\mathrm{CH}_{2^{-}}$ $\mathrm{CH}_{3}$ and $\mathrm{CO}_{3}{ }^{2-}$ absorption.

identification by FTIR, at a micrometer scale, of the replacement of sulfates by carbonates implies a mechanism of sulfato-reduction such as BSR and/or TSR, whereby sulfates are reduced by hydrocarbons with a concomitant oxydation of the organic matter (discussed in Guilhaumou et al., 2004).

\subsection{Modeling}

These results combined with PVT modeling and microthermometry of aqueous coeval fluid inclusions lead us to include the hydrofracturations and diagenetic veining during the reduction of precocious sulfates and calcite precipitation along an increase of temperature. The onset at $90^{\circ} \mathrm{C}-200$ bars and final temperatures up to $150^{\circ} \mathrm{C}$ suggest a thermosulfatoreduction mechanism (TSR) instead of a BSR. However the two mechanisms may have followed each other. The reactants may be organic acids during a first input of organic matter rich in $\mathrm{CO}_{2}$ and then a mixture of light $\left(\mathrm{CH}_{4}\right.$ rich) hydrocarbons and waters coming from compaction and meteoritic infiltration. 

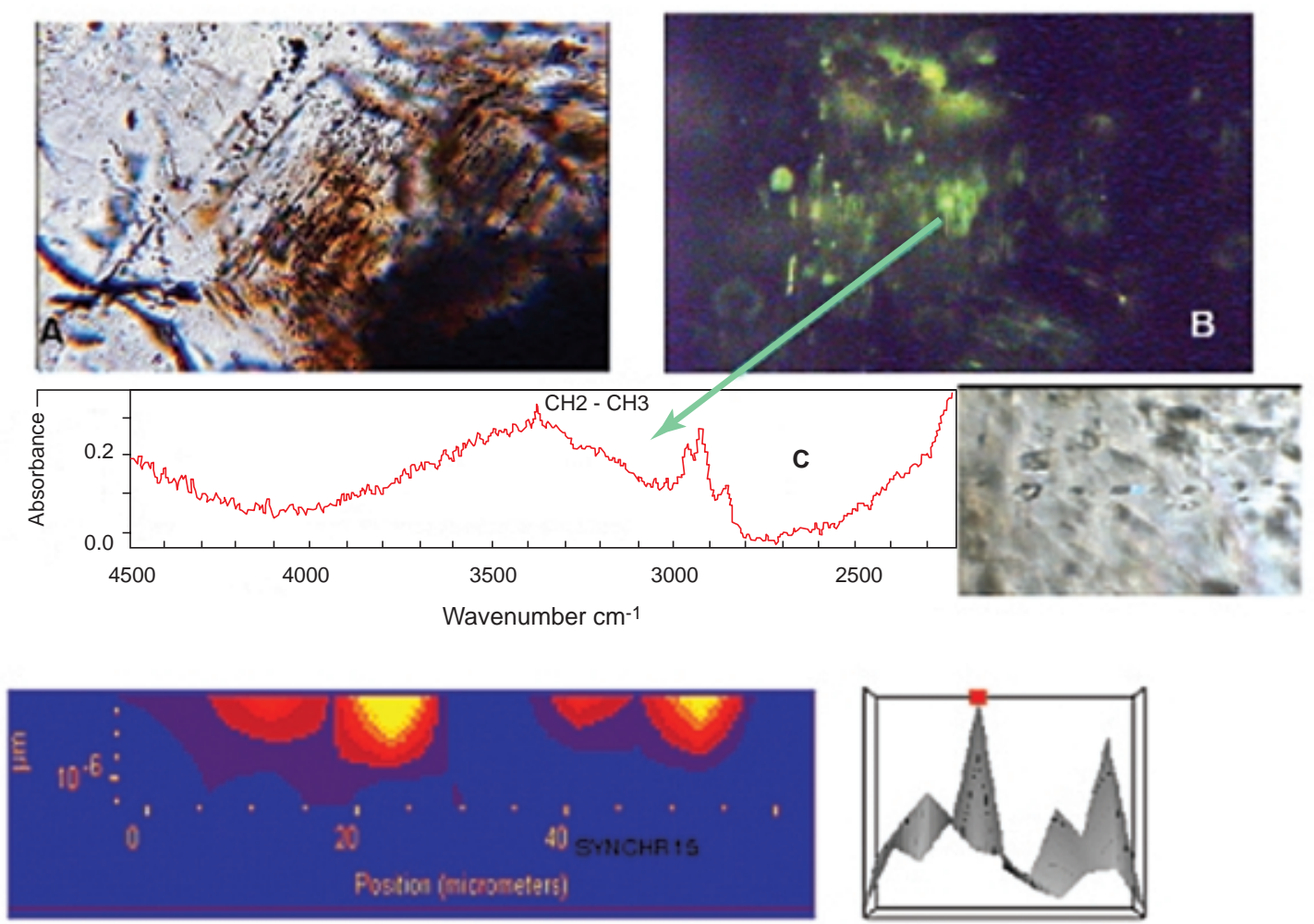

Figure 15

Molecular mapping of small size $(10 \mu \mathrm{m})$ pseudosecondary fluid inclusions in quartz along external crystal growth. Microphotographs in transmittted light (A) and fluorescence (B). The composition calculated from FTIR spectra (C) is: $\mathrm{C}_{12}$ equ. chain length for alkanes, $60 \mathrm{~mol} \% \mathrm{CH}_{4}, \mathrm{CO}_{2}$ undetected. $\mathrm{H}_{2} \mathrm{O}$ is presently in heterogeneous phase (large absorption in 4000-3200 range). The mapping of the alkane absorption (in the range $3000-2800 \mathrm{~cm}^{-1}$ ) confirms the relative homogeneity of the FI's content (homogeneous trapping) and their distribution along crystal growth.

\section{GENERAL CONCLUSION}

The combination of in situ micro FTIR analyses using a synchrotron source in the mid infrared range with PVT modeling of included oil is very appropriate for collecting informative data from individual hydrocarbon fluid inclusions. These inclusions are known to have fossilized the conditions of fluid circulation linked to diagenesis and hydrocarbon migrations in petroleum reservoirs. Information from local microanalysis confirms that several generations of coeval hydrocarbon and water FI's are usually entrapped in a single crystal and sometimes in heterogeneous trapping. For PVT modeling and trapping Pressure and Temperature calculation, the homogenisation temperature of each hydrocarbon FI generation has to be linked to the specific FI composition. Individual extraction of each FI content may be performed in exceptionally large fluid inclusions but, in most of samples, these destructive methods are not selective enough. Sensitivity tests have shown that the main parameters controlling both the liquid vapor curve and slope of the isochores of entrapped oil are the hydrocarbon chain length and the methane content. $\mathrm{CO}_{2}$ has little effect, and mixing with water may also change these parameters depending of the hydrocarbon/water volume ratio. Individual microanalyses were successfully performed by FTIR using a synchrotron source coupled to a confocal microscope, and using an internal calibration, allowing the isochoric P-T path of each fluid inclusion generation to be calculated. The method for semiquantitative microanalysis was first validated on two case studies in exceptionally large-sized hydrocarbon FI's allowing both synchrotron FTIR and GCMS analyses after individual extraction. Analysis and mapping at a micron scale of the overall solid and liquid components in entrapped oil reveal some key aspects for the understanding of diagenetic mechanisms such as porosity changes by thermosulfato reduction in reservoirs where evaporites first deposited. Microanalysis at various temperatures pinpoints the effect of $\mathrm{CO}_{2}$ dissolved in oil on the dissolution recristallisation process of carbonate seeds. Consequently, the presence of $\mathrm{CO}_{2}$ rich oil would definitively not in this case preserve the reservoir from diagenetic recristallisation of carbonates. The link to precise petrography, sedimentology and maturation of organic matter 
(Genex , IFP software) and the final input of these data in 3D geological kinetic modeling such as Thrustpack (IFP software) helps to define the path and time scale of fluid circulations and diagenetic evolutions during successive sedimentary and tectonic events.

Important information for exploration has been determined in various geological areas (Roure et al., 2004, 2005) and particularly in the foothills areas such as the subandin basins (Eastern Venezuela and Eastern Colombia), and southwestern foothills of the Himalayas (North Quirtar range, and Potwar basin, Pakistan) where exploration is mainly focused at present. Without doubt, infrared microscopy, using a synchrotron source, offers great potentialities for understanding the mechanisms controlling the diagenetic evolutions in relation to the tectonic events in petroleum reservoirs.

\section{ACKNOWLEDGMENTS}

We greatfully acknowledge Thiery Marin (LURE) for helpful technical assistance, Lakdar Benchilla during his $\mathrm{PhD}$ (IFP, Geological department) Nathalie Schildknecht (IFP, Analyical Department, Lyon) for infrared expertise, and Pascal Mougin (IFP, Thermodynamic Department) for fruitful collaboration all along these works. François Roure (IFP geological department) for managing the projects, and scientific collaboration, all the Subtrap team and students. Tarik Jaswal and Kursheed Aktar from OGDC provided the samples of Pakistani areas and financial support. Two anonymous reviewers helped to improve a first draft .

\section{REFERENCES}

Aplin, A.C., Macleod, G., Larter, S.R., Pedersen, K.S. and Booth, T. (1999) Combined use of confocal laser scanning microscopy and PVT simulation for estimating the composition and physical properties of petroleum in fluid inclusions. Marine and Petroleum Geology, 16, 97-110.

Aplin, A.C., Larter, S.R., Bigge, M.A., Macleod, G., Swarbrick R.E. and Grunberger D. (2000) PVTX history of the North Sea's Judy oil field. Journal of Geochemical Exploration, 69-70, 641644.

Barker, C. and Underwood, W.D. (1992) Analysis of gases in individual fluid inclusions in natural minerals using a dual Mass spectrometer system. The Analyst, 117, 1407-1411

Baudelet F. et al. (2005) SOLEIL a new powerful tool for materials science. $O G S T$, This issue.

Barres O., Burneau A., Dubessy J. and Pagel M. (1987) Application of micro FTIR spectroscopy to individual hydrocarbon fluid inclusion analysis. Appl. Spectrosc., 41 (6), 1000-1008.

Benchilla L. (2003) Circulation des fluides et diagenèse des réservoirs carbonatés et gréseux dans les fronts des chaînes plissées et leur avant-pays: le cas du Salt-Range-Potwar (Pakistan). PhD Thesis/Thèse, university of Leuven, Belgium, 160.

Benchilla, L., Guilhaumou, N., Mougin, P., Jaswal, T., and Roure, F., (2003). Reconstruction of palaeo-burial history and pore fluid pressure in foothill areas: a sensitivity test in the hammam Zriba (Tunisia) and Koh-i-Maran (Pakistan) ore deposits. Geofluid, 3, 103-123.

Berreby, L., (1983). PHD Thesis,/ Thèse Paris VI , France, 85.

Bouhlel, S., Fortuné, J. P., Guilhaumou, N. and Touray, J.-C. (1988).- Les minéralisations stratiformes à F-Ba de Hammam Zriba, Jebel Guébli (Tunisie nord-orientale) : l'apport des études d'inclusions fluides à la modélisation génétique. Mineral. Deposita, 23, 166-173.

Colthup, N.B. Daly, L. H., and Wiberly, S.,E. (1990) Introduction to infrared and Raman Spectroscopy. Third edition, Academic press, 547.

Cordon, S., and Guilhaumou, N., (1995) Températures de silicification des grés du Brent, Jurassique moyen, du champ de Dunbar, Mer du Nord, secteur britannique. C.R. Acad. Sci.320, 563-569.

Ellouz, N., Lafargue, E., Prinzhoffer, A., Malik, A., Jaswal, T., and Maqsood, T. (1995). Petroleum system of Sulaiman \& North Kirthar Ranges Pakistan. IFP-OGDC, repor 42.13-2.

Farmer, V.C, (1974) The infrared spectra of minerals, London, Mineralogical Society.

George, S.C, Eadington, P.J., Lisk, and M., Quezada, R. A.(1998) Contraining the oil charge history of the South Peper oil field from the analysis of oil bearing fluid inclusions, Organic Geochemistry, 29, 631-648.

Goldstein, R. H. and Reynolds, T. J. (1994) Systematics of fluid inclusions in diagenetic minerals. Society for Sedimentary Geology, Short Course, 31, 199.

Goldstein, R.H. (2001) Fluid inclusions in sedimentary and diagenetic systems. Lithos, 55, 159-193

Guilhaumou, N., Touray, J.C. and Bouhlel, S. (1988) Stretching of hydrocarbon fluid inclusions in fluorite at 200 and 400 bars confining pressure. Application to low-pressure geobarometry. Bull. Minéral., 111, 421-426.

Guilhaumou, N., (1989) Apport de l'étude des inclusions fluides intracristalllines a la diagenèse, l'anchizone et les minéralisation associées, PHD Thesis/Thèse Université d' Orléans 106.

Guilhaumou, N. Szydlowski, N., \& Enguehard, F. (1990a) MicroFTIR analysis of hydrocarbon bearing fluid inclusions. Qualitative and quantitative aspects. PACROFI III, Abstract, 3, 39 and IFP report $\mathrm{N}^{\circ} 3822$.

Guilhaumou, N., Szydlowski N. and Pradier B. (1990b).Characterization of hydrocarbon fluid inclusions by infra-red and fluorescence microspectrometry. Min. Mag., 54, 311-324.

Guilhaumou, N., Cordon, S., Durand, C. and Sommer, F. (1998a) $\mathrm{P}-\mathrm{T}$ conditions of silicification in sandstones from the Brent Group of Dunbar (North Sea). Eur. J. Mineral. 10, 355-366.

Guilhaumou, N., Dumas, P., Carr, G.L. and Williams, G.P. (1998b) Synchrotron Infrared Microspectrometry applied to petrography in the micron scale range: Fluid chemical analysis and mapping. Applied Spectroscopy, 52, 8, 176-184.

Guilhaumou, N., Ellouz, N., Jaswal, T. M. and Mougin, P. (2000).- Genesis and evolution of hydrocarbon entrapped in fluorite deposits of Koh-i-Maran (North Kirthar Range, Pakistan). Marine and Petroleum Geology, 17, 1151-1164.

Guilhaumou, N., Benchilla, L, Mougin, P. and Dumas, P. (2004) Advances in hydrocarbon fluid inclusion microanalysis and PVT modelling: Diagenetic history, P-T and fluid flow reconstruction, a case study in the North Potwar basin, Pakistan. A.A.P.G Bull. Special Memory, 1-16.

Herzberg, H., (1951).II IR and Raman microspectra of polyatomic molecules In "Molecular spectra and Molecular structures". Elsevier, 632.

Jones, D. M., Macleod, G., Larter, S. R., Hall, D. L., Aplin, A. C. and Chen, M. (1996).- Characterisation of the molecular 
composition of included petroleum. In P. E. Brown. S. G. Hagemann, eds., Biennial pan-American conference on research on fluid inclusions PAC-ROFI VI, abstract, USA, 64-65.

Karlsen, D., Nedkvitne, T., Larter, S. R. and Bjørlykke, K. (1993).- Hydrocarbon composition of authigenic inclusions : Applications to elucidation of petroleum reservoir filling history. Geochimica et Cosmochimica Acta, 57, 3641-3659.

Khorasani, G.K. (1986) Novel development in fluorescence microscopy of complex organic mixtures: Application in petroleum geochemistry. Org. Geochem.11(3), 157-168.

Larroque, C, Guilhaumou, N., Stephan, J. F. and Roure F. (1996). Large scale advection of fluids at the front of the Sicilian Neogene subduction complex. Tectonophysics, 254, 1-2, 41-56.

Legodi, M.A., de Waal, D., Potgieter, J.K., and Potgieter, S.S. (2001) Rapid determination of $\mathrm{CaCO} 3$ in mixtures utilizing FTIR Spectoscopy. Mineral Enginering, 14, N9, 1107-1111.

Macleod, G., Larter, S. R., Aplin, A. C. and Petch, G. S. (1994).Improved analysis of petroleum fluid inclusions : Application to reservoir studies. Abstracts of the American Chemical Society, 207, 132.

Macleod, G., Larter, S. R., Aplin, A. C. and Bigge, M. A. (1995).- The application of petroleum bearing fluid to tracking petroleum evolution. In : European Association of Geoscientists and Engineers, 57th Conference and Technical Exhibition, Paper F033, Glasgow.

Macleod, G., Larter, S. R., Aplin, A. C., Pedersen, K. S. and Booth, T. A. (1996).- Determination of the effective composition of single petroleum inclusions using Confocal Scanning Laser Microscopy and PVT simulation. In P. E. Brown, S. G. Hagemann, eds., Biennial Pan-American Conference on Research on Fluid Inclusions PACROFI VI, abstract 81-82.

Mandal, P.,K. and Mandal, T., K. (2002) Anion water in Gypsum $\left(\mathrm{CaSO}_{4} \cdot 2 \mathrm{H}_{2} \mathrm{O}\right)$ and hemihydrate $\left(\mathrm{CaSO}_{4} \cdot 1 / 2 \mathrm{H}_{2} \mathrm{O}\right)$. Cement and Concrete Research 32, 313-316.

Mc Limans, R.K. (1987) The application of fluid inclusions to migration of oil in diagenesis in petroleum reservoirs. Applied Geochemistry, 2 ,585-603.

Mohsin, S. I., Farooqi, M. A. and Quadri, M. U. (1983) Distribution and controls of barite-fluorite-sulphide mineralisation in the Kirthar-Sulaiman fold belt, Pakistan. Acta. Universitatis Carolinae, Geologica $\mathbf{n}^{\circ} \mathbf{3}, 237-249$.

Montel, F. (1993) Phase equilibria needs for petroleum exploration and production industry. Fluid Phase Equilibria, 84, 343-367.

Mougin, P. (1999) Méthode d'estimation de la composition des inclusions fluides à hydrocarbures par données PVT. I.F.P internal report $\mathbf{n}^{\circ} \mathbf{5 2 6 8 8}, 33$.

Murrray, R.C. (1957) Hydrocarbon Fluid inclusions in quartz. AAPG Bull., 41,950-956.

Pierre, C., and Rouchy, J.M. (1988). Carbonate replacements after sulfate evaporites in the middle Miocene of Egypt. Journal of Sedimentary Petrology, 58, N³,446-456.

Pironon, R. and Barres, O. (1990) Semiquantitative FTIR microanalysus limits: Evidence from synthetic hydrocarbon fluid inclusions in sylvite. Geochim. Cosmochim. Acta, 54, 509-518.
Pironon, R., Thiery, R., Ayt Ougougdal, M., Teinturier, S., Baudouin, S. and Walgenwitz, F. (2001). FTIR measurements of petroleum fluid inclusions: Methane, n-alkanes and carbon dioxide quantitative analysis. Geofluids, 1, 2-10.

Polack, F., Mercier R., et al. 1999. «Optical design and performance of the IR microscope beamline at SuperACOFrance.» SPIE (eds G.L.Carr, P. Dumas) 3575- 3583.

Rankin, A. H., Hodge, B. L. and Moser, M. (1990).- Unusual oilbearing inclusions in fluorite from Baluchistan, Pakistan. Mineralogical Magazine, 54, 335-342.

Reffner, J. A., Martoglio, P., Williams, G. P., (1995) Fourier Transform infrared microscopical analysis with Synchrotron radiation: The microscope optics and system performance. Rev. Sci. Instr. 66, 1298-1305.

Richardson, C.K. and Pinckney, D.M. (1984).- The chemical and thermal evolution of the fluid in Cave in Rock fluorspar district, Illinois: Mineralogy, paragenesis and fluid inclusions. Econ. Geol., 79, 1833-1836.

Reffner, J. A., Martoglio, P., Williams, G. P.(1995) Fourier Transform infrared microscopical analysis with Synchrotron radiation: The microscope optics and system performance. Rev. Sci. Instr. 66, 1298-1305.

Roedder, E. (1984). Fluid inclusions, reviews in Mineralogy, v 12, Blacksburg, Mineralogical Society of America, 644.

Roure, F., Bordas-Lefloch, N., Augsbourg , C., Guilhaumou, N., Lecornec-Lance, S., Hernandez, E., Sassi, W., Toro, J., and Robion, P. (2004) Petroleum system and reservoir apraisal in the subandean Basins of eastern Venezuela and eastern Colombian foothills. AAPG Bull. Special Memory, 34, 1-25

Roure, F., Schneider, F., Faure, J.L., Ferket, H., Guilhaumou, N., Osadetz, K., Robion, P., and Vandeginste, V. Incidence and importance of tectonics and natural fluid migration on reservoir evolution in foreland fold and thrust belts (2005) OGST, in press.

Salisbury, J. W.,Walter, L.S., Vergo, N. and D'Aria, D.M., (1991) Infrared 2-15m spectra of minerals, Baltimore, Maryland, John Hopkins University Press.

Sassi, W. and Rudkiewicz, J.L., (1996), Thrustpack, version 3.3: 2D integrated maturity studies in thrust areas: Institut Français du Pétrole report 43393,113

Sassi, W. and Rudkiewicz, J.L., (2000) Computer modeling of petroleum systems along regional cross section in foreland and fold and thrustbelts. EAGE, Annual Meeting, Malta, Abstract.

Rudkiewicz, J.L., Brévart, O., Connan, J. and Montel, F. (1994) Primary migration behaviour of hydrocarbons : from laboratory experiments to geological situation through fluid flow models. Organic Geochemistry, 22 (3-5) 631-639.

Thiery, R., Pironon, J., Walgenwitz, F., and Montel, F. (2000) PIT (Petroleum inclusion Thermodynamic): a new modeling tool for the characterization of hydrocarbon fluid inclusions from volumetric and microthermometric measurements. Journal of Geochemical Exploration, 69-70, 701-704.

Ungerer, P., and Batut, C. (1997).- Prédiction des propriétés volumétriques des hydrocarbures par une translation de volume améliorée. Revue de l'Institut Français du Pétrole, 52, pp. 609-623.

Final manuscript received in March 2005 


\section{APPENDIX}

\section{Quantitative Infrared Analysis}

\section{Alkane Chain Length Estimation}

In liquid hydrocarbons, aliphatics are characterized principally by the symmetric and antisymmetric stretching vibration of the $-\mathrm{CH}_{3}$ and the $-\mathrm{CH}_{2}$ groups. Theoretically the absorption intensities of the bands at 2850 and $2920 \mathrm{~cm}^{-1}$ $\left(v_{\mathrm{a}}\right.$ and $\left.\mathrm{v}_{\mathrm{s}} \mathrm{CH}_{2}\right)$ and 2873 and $2959 \mathrm{~cm}^{-1}\left(\mathrm{v}_{\mathrm{a}}\right.$ and $\left.\mathrm{v}_{\mathrm{s}} \mathrm{CH}_{3}\right)$ are function respectively of the number of $\mathrm{CH}_{2}$ and $\mathrm{CH}_{3}$ groups in the structure (Herzberg 1951, Colthup et al., 1991). An additional band of C-H at $2890 \mathrm{~cm}^{-1}(\mathrm{v}-\mathrm{CH})$ and the band of $\mathrm{CH}_{4}\left(\mathrm{v}-\mathrm{CH}_{4}, \mathrm{q}\right.$ and $\mathrm{r}$ branch) being superimposed in various proportions. As the absorbance of $\mathrm{n}-\mathrm{CH}$ is not known, we chose to neglect it. For $\mathrm{CH}_{4}$ a reference spectrum is recorded in the same conditions and subtracted from the alkane massif. We chose fluid inclusions from the Alps, containing pure $\mathrm{CH}_{4}$ under low pressure (checked by Raman analysis) considered as a reference. A calibration curve is established from $\mathrm{C}_{6}$ to $\mathrm{C}_{15}$ with pure alkane standards by measuring the ratios of the pseudo areas relative to $\mathrm{CH}_{2}$ and $\mathrm{CH}_{3}$.

Refering to this curve, some $\mathrm{CH}_{3} / \mathrm{CH}_{2}$ ratios were calculated integrating the pseudoareas and compared with the results obtained on a set of large fluid inclusions analysed by GCMS (Guilhaumou et al., 2000) following the procedure described hereafter. Results show that FTIR chain lengths so determined are lower by about two carbon refering to the CG alkane chain length so calculated.

\section{Gas Chromatographic Analysis}

The extraction of the liquid organic content of large inclusions in fluorite $(>100 \mu \mathrm{m})$ was made under a Wild macroscope (X10 to 50) using a drilling tool controled by a micromanipulator. The sample was set up in a capsule containing pure dichloroethane (used as solvent for GCMS analyses). Analyses were made on a HP 5890 A chromatograph, equipped with an FID detector and a 50m apolar (Chromopack Cpsil 5CB) capillary column of $1 \mathrm{~mm}$ diameter. This extraction procedure may control the individual fluid inclusion content, but cannot take into account the light fraction $\left(<\mathrm{C}_{6}\right)$ which partly evaporates. Moreover, the distinction between solvent and $\mathrm{C}_{5}$ peaks is not always possible in the chromatogram. As peak areas on the chromatogram are proportional to the mass abundance of each alkane, we calculated a molecular $\mathrm{CH}_{3} / \mathrm{CH}_{2}$ ratio with the following formula:

$$
\frac{\mathrm{mCH}_{3} \text { total }}{\mathrm{mCH}_{2} \text { total }}=\frac{\sum_{i} 2 \mathrm{~A}_{\mathrm{i}} /(14 \mathrm{i}+2)}{\sum_{i}(\mathrm{i}-2) \mathrm{A}_{\mathrm{i}} /(14 \mathrm{i}+2)}
$$

with $\mathrm{m}=$ molar, $\mathrm{A}_{\mathrm{i}}$ the peak area of a $\mathrm{n}$ alkane with $\mathrm{i}$ carbon atoms, thus containing $2 \mathrm{CH}_{3}$ groups and (i-2) $\mathrm{CH}_{2}$ groups of molecular abundance $\left(\mathrm{A}_{\mathrm{i}} / 14 \mathrm{i}+2\right)$.

We calculated a chain length proposed as an alkane equivalent.

\section{Isochoric Modeling}

To estimate PVT information about the hydrocarbons trapped in an inclusion, we need an approximation about the composition of this fluid. Generally, natural hydrocarbon distributions follow a relationship such as (Montel, 1993):

$$
x_{n}=\alpha\left(1-\frac{\beta}{n}\right) x_{n-1}
$$

where $x_{n}$ and $x_{n-1}$ are the molar fractions of hydrocarbon with respectively $n$ and $n-1$ atoms of carbon. $\alpha$ and $\beta$ are two parameters relative to the composition. The parameters $(\alpha, \beta$, representative of hydrocarbon composition are optimized and improved progressively (Ungerer and Batut, 1997; Mougin, 1999; Guilhaumou et al., 2000; Benchilla, 2003). We add a third parameter which is the estimation of the $\mathrm{CO}_{2}$ content. The three parameters are fitted to the experimental data such as the composition measured by FTIR, the liquid vapor ratio at room temperature and the homogenisation temperature measured by microthermometry.

The simulator determines the phase envelopes and the pressure-temperature by PVT iterative calculations series using the Peng-Robinson's equation of state and the IFP database. 